\title{
Growth and yield of mixed versus pure stands of Scots pine (Pinus sylvestris L.) and European beech (Fagus sylvatica L.) analysed along a productivity gradient through Europe
}

\author{
H. Pretzsch ${ }^{1}$ - M. del Río ${ }^{2}$ - Ch. Ammer ${ }^{3}$ - A. Avdagic ${ }^{4}$ I. Barbeito ${ }^{5}$. \\ K. Bielak ${ }^{6}$ - G. Brazaitis ${ }^{7}$ - L. Coll ${ }^{8}$ G. Dirnberger ${ }^{9}$ L. Drössler ${ }^{10}$ •

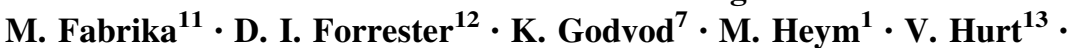 \\ V. Kurylyak ${ }^{14} \cdot$ M. Lö ${ }^{10} \cdot$ F. Lombardi ${ }^{15} \cdot$ B. Matović ${ }^{16} \cdot$ F. Mohren ${ }^{17}$. \\ R. Motta ${ }^{18}$ - J. den Ouden ${ }^{17} \cdot$ M. Pach ${ }^{19} \cdot$ Q. Ponette ${ }^{20}$ - G. Schütze ${ }^{1}$.

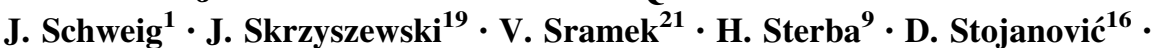 \\ M. Svoboda ${ }^{22} \cdot$ M. Vanhellemont ${ }^{23} \cdot$ K. Verheyen $^{23} \cdot$ K. Wellhausen ${ }^{1}$. \\ T. Zlatanov ${ }^{24}$ - A. Bravo-Oviedo ${ }^{2}$
}

Received: 9 June 2015/Revised: 8 July 2015/Accepted: 15 July 2015/Published online: 23 July 2015

(C) The Author(s) 2015. This article is published with open access at Springerlink.com

\begin{abstract}
Mixing of complementary tree species may increase stand productivity, mitigate the effects of drought and other risks, and pave the way to forest production systems which may be more resource-use efficient and stable in the face of climate change. However, systematic empirical studies on mixing effects are still missing for many commercially important and widespread species
\end{abstract}

Communicated by Peter Biber.

Electronic supplementary material The online version of this article (doi:10.1007/s10342-015-0900-4) contains supplementary material, which is available to authorized users.

H. Pretzsch

Hans.Pretzsch@1rz.tum.de; H.Pretzsch@1rz.tum.de

1 Chair for Forest Growth and Yield Science, Technische Universität München, Hans-Carl-von-Carlowitz-Platz 2, 85354 Freising, Bavaria, Germany

2 Department of Silviculture and Forest Systems Management, INIA-CIFOR, Madrid, Spain

3 Abteilung Waldbau und Waldökologie der gemäßigten Zonen, Georg-August-Universität Göttingen, Göttingen, Germany

4 Institute for Forestry and Landscape Architecture, Faculty of Forestry, Sarajevo, Bosnia-Herzegovina

5 Laboratoire d'Etude des Ressources Forêt Bois (LERFoB), INRA Centre of Nancy, Champenoux, France

6 Department of Silviculture, Warsaw University of Life Sciences, Warsaw, Poland

7 Institute of Forest Biology and Silviculture, Aleksandras Stulginskis University, Kaunas, Lithuania combinations. Here we studied the growth of Scots pine (Pinus sylvestris L.) and European beech (Fagus sylvatica L.) in mixed versus pure stands on 32 triplets located along a productivity gradient through Europe, reaching from Sweden to Bulgaria and from Spain to the Ukraine. Stand inventory and taking increment cores on the mainly 60-80 year-old trees and $0.02-1.55$ ha sized, fully stocked plots provided insight how species mixing modifies the structure, dynamics and productivity compared with neighbouring pure stands. In mixture standing volume $(+12 \%)$, stand density $(+20 \%)$, basal area growth $(+12 \%)$, and stand volume growth $(+8 \%)$ were higher

8 Investigador del Centre Tecnològic Forestal de Catalunya (CTFC), Solsona, Spain

9 Department of Forest and Soil Science, BOKU University of Natural Resources and Life Sciences, Vienna, Austria

10 Southern Swedish Forest Research Centre, Swedish University of Agricultural Sciences, Alnarp, Sweden

11 Department of Forest Management and Geodesy, Faculty of Forestry, Technical University in Zvolen, Zvolen, Slovakia

12 Chair of Silviculture, Albert-Ludwigs-Universität Freiburg, Freiburg, Germany

13 Department of Silviculture, Mendel University, Brno, Czech Republic

14 Forestry Academy of Sciences of Ukraine, Lviv, Ukraine

15 Dipartimento di Bioscienze e Territorio (DIBT), University of Molise, Pesche, Italy

16 Institute of Lowland Forestry and Environment, University of Novi Sad, Novi Sad, Serbia 
than the weighted mean of the neighbouring pure stands. Scots pine and European beech contributed rather equally to the overyielding and overdensity. In mixed stands mean diameter $(+20 \%)$ and height $(+6 \%)$ of Scots pine was ahead, while both diameter and height growth of European beech were behind $(-8 \%)$. The overyielding and overdensity were independent of the site index, the stand growth and yield, and climatic variables despite the wide variation in precipitation $\left(520-1175 \mathrm{~mm} \mathrm{year}^{-1}\right)$, mean annual temperature $\left(6-10.5^{\circ} \mathrm{C}\right)$, and the drought index by de Martonne (28-61 mm ${ }^{\circ} \mathrm{C}^{-1}$ ) on the sites. Therefore, this species combination is potentially useful for increasing productivity across a wide range of site and climatic conditions. Given the significant overyielding of stand basal area growth but the absence of any relationship with site index and climatic variables, we hypothesize that the overyielding and overdensity results from several different types of interactions (light-, water-, and nutrient-related) that are all important in different circumstances. We discuss the relevance of the results for ecological theory and for the ongoing silvicultural transition from pure to mixed stands and their adaptation to climate change.

Keywords Overyielding - Overdensity - Modulation of growth curves $\cdot$ Stress gradient hypothesis $\cdot$ Light interception $\cdot$ Risk distribution

\section{Introduction}

Recent empirical studies of mixed forest long-term experiments (Bielak et al. 2014; Pretzsch et al. 2010, 2013a), studies using large-scale data bases (del Río and Sterba 2009; Río et al. 2014a; Vallet and Perot 2011), simulation

17 Forest Ecology and Forest Management, Wageningen University of Environmental Sciences, Wageningen, The Netherlands

18 Department of Agricultural, Forest and Food Sciences DISAFA, University of Turin, Turin, Italy

19 Department of Silviculture, Institute of Forest Ecology and Silviculture, University of Agriculture, Kraków, Poland

20 Faculty of Bioscience Engineering and Earth and Life Institute, Université catholique de Louvain, Louvain-la-Neuve, Belgium

21 Forestry and Game Management Research Institute, Opocno, Czech Republic

22 Faculty of Forestry and Wood Sciences, Czech University of Life Sciences, Prague, Czech Republic

23 Forest and Nature Lab, Ghent University, Melle-Gontrode, Belgium

24 Department of Silviculture, Forest Research Institute, Sofia, Bulgaria model studies (Morin et al. 2011), as well as meta-analyses (Griess and Knoke 2011; Paquette and Messier 2011; Piotto 2008; Zhang et al. 2012), showed that the productivity of mixed stands can exceed the weighted mean productivity of pure stands. This overyielding can reach $50 \%$ in mixture with nitrogen-fixing species (Forrester et al. 2006) and 20-30\% in other mixtures (Pretzsch et al. 2013a). Species mixing can trigger emergent properties, e.g., allometric plasticity (Dieler and Pretzsch 2013; Pretzsch 2014), spatial niche separation above and below ground (Richards et al. 2010), or hydraulic redistribution (Caldwell et al. 1998), and can improve the supply, capture, or use efficiency of resources and thereby increase productivity (Forrester 2014, 2015) of mixed compared with pure stands.

A better understanding of the underlying causes of overyielding/underyielding is essential for both science and practice. Clarification might improve theory of species mixing, model approaches, and prediction. A better understanding also may contribute to design of forest production systems which are more resource efficient, resistant and resilient in the face of climate change (Forrester 2014). Insight into mixed-species stands is so far based either on in depth mechanistic analysis of forest systems at selected sites and therefore hardly generalizable (Häberle et al. 2012; Pretzsch et al. 2014) or on statistical analyses which provide little insight into the underlying causes of overyielding or underyielding (Griess and Knoke 2011; Piotto 2008). Studies along ecological gradients which improve the understanding of the site-dependent interactions between the species in mixed stands are available for herbaceous (Holmgren et al. 1997) but hardly for woody plants (Forrester 2014).

Here we study the effect of inter- versus intra-specific neighbourhoods of Scots pine (Pinus sylvestris L.) and European beech (Fagus sylvatica L.) on 32 triplets located along a productivity gradient through Europe. The set of triplets covers the natural distribution of the overlap of these species and should therefore provide a good representation of any overyielding and its variation in time (retrospective growth analyses based on increment cores) and space (along the productivity gradient through Europe).

\section{High relevance of mixed stands of Scots pine and European beech}

As the rather Atlantic distribution range of European beech and the more continental range of Scots pine overlap, mixed stands of both species are of considerable importance in Europe. Scots pine covers about $12 \times 10^{6}$ ha and European beech $49 \times 10^{6}$ ha. The potential area where both species can mix amounts to $32 \times 10^{6}$ ha, but the 
current area of mixed stands of Scots pine/European beech stands is only $1.7 \times 10^{6}$ ha (Brus et al. 2011). These forests, especially pure and mixed European beech stands, have been severely decimated by clearing for agriculture and, during the last few centuries, by replacing them with faster and straighter growing conifers such as Norway spruce (Mantel 1961). Without human interference beech would probably currently cover more than $2 / 3$ of the Central European forest area (Bohn et al. 2003) and therefore can be considered as the most competitive Central European tree species (Leuschner et al. 2006). In reality, its current share in the forested lands has been reduced to less than $1 / 5$ by human interference (Bolte et al. 2007; Fischer and Fischer 2012).

The admixture of shade tolerant (European beech) and intolerant (Scots pine) tree species is likely to produce a multi-layered canopy, a large variety of stem diameters and heights, and a complex horizontal arrangement of stems (Spies and Franklin 1991; McElhinny et al. 2005). Increased horizontal and vertical structural complexities are assumed to be positively associated with biodiversity (Zellweger et al. 2013) and favour habitat structure for many taxa. Moreover, as Scots pine and European beech are vulnerable to completely different disturbances, mixed stands vs. pure stands are associated with smaller-scale catastrophic events (Kint et al. 2006).

\section{Limited knowledge of mixing effects between Scots pine and European beech}

Regional studies by Bielak et al. (2015), Bonnemann (1939), Condés et al. (2013), Gabriel et al. (2005), Metz et al. (2013), Pirogowicz (1990), and Pretzsch et al. (2013c) reported beneficial interactions and overyielding for Scots pine and European beech mixtures. The complementarity of their ecological traits might cause overyielding at present and may become even more relevant and stabilizing in the future under climate change. Mixing of light demanding with shade tolerant species may increase the light interception due to contrasting speciesspecific light compensation points and light-use efficiencies. Beech may be well equipped to forage for light beside or below Scots pine. In return, Scots pine may profit from higher light and water availability in spring before the admixed beech flushes, starts using water and shading the Scots pine (Assmann 1970, pp. 39-40). Bonnemann (1939, Fig. 20) also reports a complementary use of the root space where beech frequently reaches down to $40-80 \mathrm{~cm}$, while pine mainly occupies the upper layer between 0 and $40 \mathrm{~cm}$. This can mean a more complete use of water and mineral nutrients when both species are combined. Beech can further improve the humus layer, upper mineral soil, and thereby facilitate Scots pine by exploitation of mineral nutrients in deeper soil layers and their addition into the nutrient cycle via litter fall (Chodzicki 1934).

The regeneration of sandy soils impoverished by repeated cultivation of pure Scots pine stands by admixture of broadleaved species assumes a positive effect of European beech on the internal climate, humus type, earthworm community and thus litter decomposition, deeper root penetration of the soil, an increase in turnover, improvement of the nutrient supply and water storage capacity and finally an increase in growth of mixed versus pure stands (Gabriel et al. 2005; Heinsdorf 1999; von Mammen et al. 2003). The stand-level combination of structurally and chemically contrasting litter types may, in the long term, improve fertility and resource storage capacity of soils (carbon, water and nutrients), perhaps mediated through stimulated bioturbation (Ammer et al. 2006; Augusto et al. 2002; Heinsdorf 1999; Rothe and Binkley 2001). Under drought stress facilitative interactions may increase due to the complementary isohydric behaviour of Scots pine and anisohydric behaviour of European beech (Hartmann 2011) or because of hydraulic lift by the deeper rooting beech in favour of Scots pine (Caldwell et al. 1998; McDowell et al. 2008).

However, limitation in precipitation (Knapp 1991) and high stocking densities (Condés et al. 2013) can also increase the inter-specific competition and cause underyielding of mixed-species stands compared with monocultures. It is therefore likely to be critical to achieve a balance between complementarity interactions that potentially reduce drought stress but that do not increase growth and stand density (and evapotranspiration) so much that water availability is reduced leading to drought stress as the stands develop (Forrester 2015). Studies of the resource conditions and growth of Scots pine and European beech in inter-specific versus intra-specific neighbourhoods are restricted to a few sites, mainly extremely poor and degraded sites which required enrichment by species mixing, fertilization, or amelioration. We are therefore far from generalizable knowledge of the causes and effects when mixing Scots pine with European beech.

\section{Reason for the high practical relevance of mixed stands of Scots pine and European beech}

The potential benefits that can be derived from mixing of complementary tree species such as pioneer Scots pine and late-successional European beech are of high interest for close-to-nature silviculture. Establishment and tending of mixed stands of both tree species may reduce their risk of damage in the face of climate change (Geßler et al. 2007) and is one of the main adaptation strategies in forest practice at present (Kolström et al. 2011). While Scots pine is quite resilient to abiotic stress (Brzeziecki and Kienast 
1994), European beech can suffer from severe frost with minimum temperatures below $-20{ }^{\circ} \mathrm{C}$ (Jönsson 2000; Czajkowski and Bolte 2006) or extreme late frosts after leaf unfolding (Fisichelli et al. 2014; Dittmar et al. 2006). According to Holmsgaard (1962), frost below $-4{ }^{\circ} \mathrm{C}$ can damage the developing shoots of European beech, reduce its growth, and result in cause deformed branches. European beech is also characterized by high drought sensitivity that significantly influences its water budget resulting also in a restricted nitrogen supply (Geßler et al. 2004). On the other hand, widespread monocultures of Scots pine suffer more often than European beech from calamities caused by insect outbreaks and fungal diseases (Knoke et al. 2008). Therefore, silvicultural strategies that favour Scots pine and European beech mixtures over monocultures should effectively mitigate damage caused by these biotic and abiotic disturbances (Ehwald et al. 1961; Kint et al. 2006). The faster growing and light demanding Scots pine can be used as nurse trees, especially in case of larger openings, to shade and protect the more slowly developing, and more sensitive European beech, against late frosts or heat stress caused by direct insolation (Schütz 2001). Moreover, Scots pine can improve European beech form by producing slender trees and limiting branch development at young stages (Prévosto and Balandier 2007). On the other hand, the introduction of European beech under the canopy of Scots pine accelerates the pruning effect and as a result enhances timber quality of pine (Pirogowicz 1990).

\section{Objectives and questions of this study}

Resource-use efficient production systems of Scots pine and European beech can only be designed, modelled, and regulated in practice if the causes of any species mixing effects are understood. To identify the emergent properties in mixed stands, mixing effects have to be traced from the stand level to the size distribution, tree and organ levels. Furthermore, their dependency on spatially and temporarily varying environmental conditions needs to be analysed. The objective of this study was to assess the relevance of mixing effects in terms of stand productivity on the 32 triplets. Therefore, this study is concerned specifically with the following questions

1. How does the volume productivity and density of mixed-species stands differ from the neighbouring pure stands?

2. How do stand state variables, such as mean tree height or mean tree diameter of Scots pine and European beech in mixed-species stands differ from pure stands?

3. How does any overyielding and overdensity of the mixed-species stands depend on the stand and site characteristics?
Coming papers will also base on the 32 triplets and deal with the underlying mechanisms of the growth reactions which are presented in this study.

\section{Materials and methods}

In order to achieve generalizable knowledge of the productivity of mixed versus pure stands of Scots pine and European beech a set of 32 triplets of mixed and pure plots was established. By locating the triplets along a stand productivity gradient (Fig. 1; Supplement Table 1) mainly determined by water supply, the mean overyielding or underyielding of mixed stands as well as the variation of any species mixing effects can be analysed. The voluntary and national-funded triplets were established by members of the COST Action FP1206 EuMIXFOR (see webpage www.mixedforests.eu) and are spread over 16 countries. The 32 triplets represent the broad range of eco-physiographical condition in Europe and extend from Sweden to Bulgaria and from Spain to the Ukraine (Fig. 2).

\section{Study area}

The triplets cover the overlap of the natural range of Scots pine and European beech very well, with triplets at the northern border in Lithuania and the southern range in Bulgaria and Spain. The study covers the far southwest region in Spain and reaches to the eastern border in the Ukraine. The highest concentration of plots is in the central European area in Germany, Belgium, the Netherlands, the Czech Republic, and Poland, where mixed stands of Scots pine and European beech have a share of up to $30 \%$ of the forest area. For the triplets in the entire study region, the mean annual temperature ranges from 6 to $10.5^{\circ} \mathrm{C}$, the annual precipitation from 520 to $1175 \mathrm{~mm}$, and the elevation from 20 to $1290 \mathrm{~m}$ a.s.l. (Supplement Table 1).

\section{Materials}

For the study we used 32 triplets (Table 1; Fig. 1). They are sets of three rectangular plots including two pure stands of Scots pine and European beech and one mixed stand of these species. The plot size varies between 0.02 and 1.55 ha. All triplets represent more or less even-aged, fully stocked and mono-layered forest stands. The plots were not thinned recently and represent approximately maximum stand density. Mixed plots represent individual tree mixtures and the mixing proportion of Scots pine varied between 18 and $72 \%$ and the mixing proportion of European beech varied correspondingly between 28 and $82 \%$.

The plots within a triplet are similar in site conditions. The pure stands are used as the reference for the mixed 
Fig. 1 Principle of the transect study: an ecological gradient from moist to dry sites including 32 triplets, consisting of pure Scots pine stands, pure European beech stands, and mixed stands of Scots pine and European beech, which were established in autumn 2013spring 2014

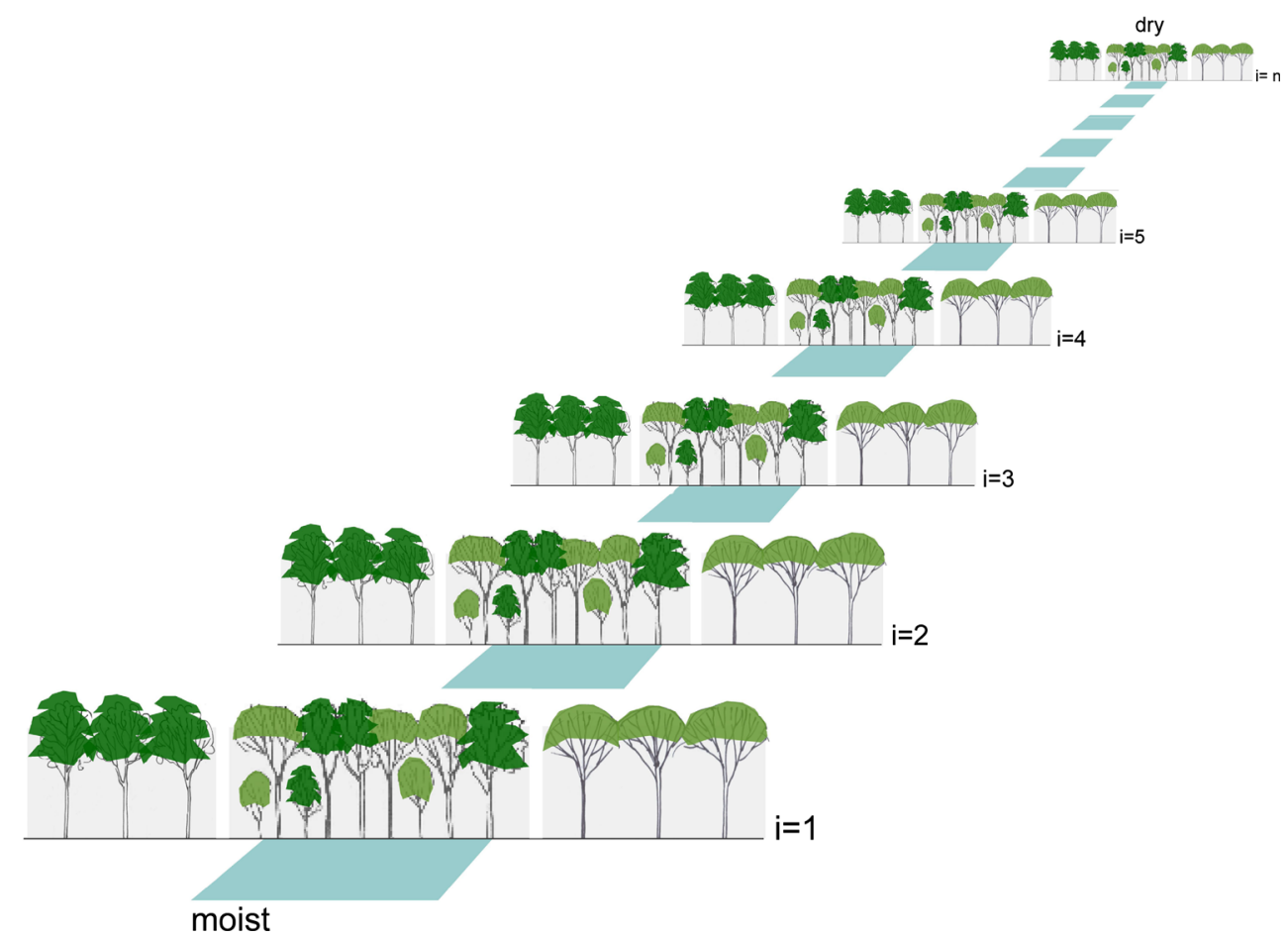

Fig. 2 Location of the 32 triplets of pure and mixed stands of Scots pine and European beech, which were established and sampled in autumn 2013spring 2014. The triplets are spread over 16 countries: Austria (Aus 1), Belgium (Bel 1-2), Bosnia-Herzegovina (BHe 1), Bulgaria (Bul 1), the Czech Republic (Cze 1-2), France (Fran 1), Germany (Ger 1-7), Italy (Ita 1-2), Lithuania (Lit 1-2), The Netherlands (Net 1), Poland (Pol 1-5), Serbia (Ser 1), Slovakia (Slo 1), Spain ( $S p$ 1-2), Sweden (Swe 1-2), and the Ukraine (Ukr 1)

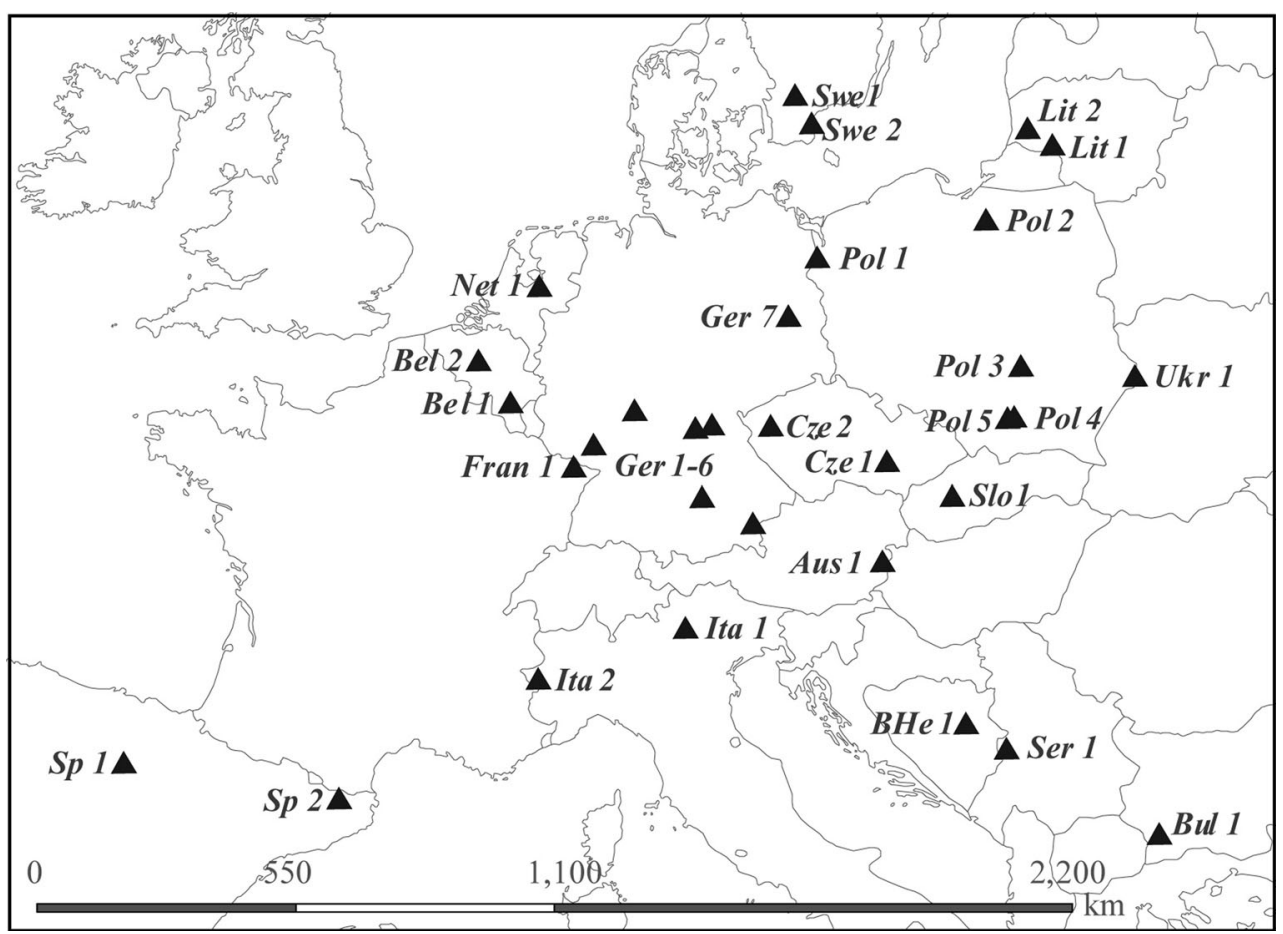

stands and for quantification of mixing effects in terms of overyielding or underyielding of mixed compared with pure stands. We inventoried the plots in order to derive the dendrometric state variables at the tree and the stand level. Supplement Table 2 gives an overview of the realized measurements of tree diameter, tree height, and sampled cores.

In order to retrospectively determine the tree and stand growth, we took increment cores from a subset of at least 20 trees per species per plot covering the diameter range of 
Table 1 Stand characteristics of the triplets of pure and mixed-species stands

\begin{tabular}{|c|c|c|c|c|c|c|c|c|}
\hline Species & $n$ & Stand age (years) & $N\left(\right.$ trees ha $\left.{ }^{-1}\right)$ & $d_{\mathrm{q}}(\mathrm{cm})$ & $h_{\mathrm{q}}(\mathrm{m})$ & BA $\left(m^{2} h^{-1}\right)$ & $V\left(\mathrm{~m}^{3} \mathrm{ha}^{-1}\right)$ & PAIV $\left(\mathrm{m}^{3} \mathrm{ha}^{-1}\right.$ year $\left.^{-1}\right)$ \\
\hline \multirow[t]{2}{*}{ Sc. pine + E. be. } & 32 & 70 & 990 & & & 40.65 & 444 & 13.6 \\
\hline & & $39-149$ & $250-2628$ & & & $15.85-77.94$ & $134-956$ & $5.1-31.2$ \\
\hline \multirow[t]{2}{*}{ Sc. pine mixed } & 32 & 70 & 405 & 32.3 & 23.1 & 23.33 & 255 & 6.0 \\
\hline & & $39-149$ & $50-1529$ & $14.0-70.1$ & $12.1-35$ & $4.35-43.48$ & $44-658$ & $1.7-13$ \\
\hline \multirow[t]{2}{*}{ E. beech mixed } & 32 & 70 & 585 & 22.3 & 20.9 & 17.32 & 189 & 7.6 \\
\hline & & $39-149$ & $127-1733$ & $11.2-46.8$ & $12.2-30.8$ & $9.61-36.78$ & $56-392$ & $3.0-18.2$ \\
\hline \multirow[t]{2}{*}{ Sc. pine pure } & 32 & 69 & 970 & 27.6 & 22.1 & 40.92 & 413 & 11.3 \\
\hline & & $39-149$ & $82-3200$ & $13.7-45.5$ & $8.7-33.9$ & $13.29-62.93$ & $162-923$ & $2.7-21.9$ \\
\hline \multirow[t]{2}{*}{ E. beech pure } & 32 & 69 & 1027 & 25.1 & 23.0 & 34.48 & 411 & 14.7 \\
\hline & & $39-149$ & $220-2745$ & $12.0-49.4$ & $12.4-34.1$ & $17.84-53.37$ & $146-959$ & $6.0-27.6$ \\
\hline
\end{tabular}

A total of 32 triplets were included consisting of 32 mixed-species stands and 64 neighbouring pure stands of the respective tree species. Growth and yield characteristics are given for the pure stands, for the species in the mixed stands, and for the mixed stand as a whole. Means of all 32 triplets are given in plain text and ranges (min-max) over all 32 triplets are given in italics. Tree number $\left(\mathrm{ha}^{-1}\right), N$, quadratic mean diameter $(\mathrm{cm}), d_{\mathrm{q}}$, quadratic mean height $(\mathrm{m}), h_{\mathrm{q}}$, stand basal area, BA $\left(\mathrm{m}^{2} \mathrm{ha}^{-1}\right)$, standing volume $V\left(\mathrm{~m}^{3} \mathrm{ha}^{-1}\right)$, mean periodic annual volume growth, $\operatorname{PAIV}\left(\mathrm{m}^{3} \mathrm{ha}^{-1}\right.$ year $\left.^{-1}\right)$

the corresponding species. From all sample trees, cores reaching the pith were extracted at $1.30 \mathrm{~m}$ stem height from the north and east directions. The annual ring width on the cores was analysed, the dendrometric time series were synchronized, and the arithmetic means of the annual ring width in the north and east directions were used for the further evaluation.

\section{Data preparation}

\section{Evaluation of stand growth and yield variables}

Stand characteristics such as mean tree dimensions, stand basal area (BA), and standing volume stock per hectare ( $V$ ) for the survey in autumn 2013-spring 2014 and also for 2009 were evaluated following DESER-Norm 1993 (Johann 1993; Pretzsch 2009, pp. 181-222). The evaluation for 2009 required the reconstruction of the stand development in the last 5 years, which is explained as follows. Based on this reconstruction the stand basal area growth, PAIBA, and the stem volume growth of the stand, PAIV, between 2009 and 2013 were calculated as PAIBA $_{2009-2013}=\mathrm{BA}_{2013}-\mathrm{BA}_{2009}+\mathrm{BA}_{\text {removal }}$, and $\mathrm{PAIV}_{2009-2013}=V_{2013}-V_{2009}+V_{\text {removal }}$.

In order to get the stand characteristics in 2009 for all trees, the diameters and heights were reconstructed. For reconstructing the diameter at breast height over bark in 2009 linear regression models (OLS regression) $i d_{2009-2013}=a_{0}+a_{1} \times d_{2013}$ were fitted for each plot and species. In latter equation id represents the stem diameter increment, $d$ the stem diameter, and $a_{0}$ and $a_{1}$ the intercept and slope of the linear model. Based on this function of diameter growth depending on diameter in autumn 2013, the tree diameter in 2009 of all cored and non-cored trees could be determined $\left(d_{2009}=d_{2013}-i d_{2009-2013}\right)$.

To reconstruct the individual tree heights of Scots pine and European beech in 2009, we used a uniform height curve system first developed for European beech by Kennel (1972, pp. 77-80) and later parameterized for Scots pine and other species by Franz et al. (1973, pp. 91-99). Using this uniform height curve system the individual tree heights are estimated as a function of their diameter via; $h=1.3+(d /$ $\left.\left(b_{1} * d+b_{0}\right)\right)^{3}$ (Petterson 1955) where $h$ and $d$ refer to the individual tree height and diameter at breast height, respectively. The parameter values $b_{0}$ and $b_{1}$ depend on stand age, quadratic mean tree diameter, $d_{\mathrm{q}}$, of the stand and its respective height, which were derived as follows: The stand age and mean tree diameter could be calculated based on the records from autumn 2013 and tree ring analyses. For reconstruction of the mean tree height in 2009, we used the height-age curves of the yield tables by Wiedemann (1943) and Schober (1967) for Scots pine and European beech, respectively. For each plot and species, the site-specific height curve (i.e., the curve running through stand age and mean height measured in autumn 2013-spring 2014) was used to predict the mean height of the stand 5 years before, i.e., in 2009. Using the individual trees' diameter and height in year $n, d_{n}$ and $h_{n}$, and their species-specific form factors, $f_{n}$, by Franz (1971), we were able to calculate the present volume $\left(v_{n}=d_{n}^{2} \times \pi / 4 \times h_{n} \times f_{n}\right)$, the volume five years ago $\left(v_{n-5}=d_{n-5}^{2} \times \pi / 4 \times h_{n-5} \times f_{n-5}\right)$, and thus their mean annual volume increment within the 5-year period $\left(i v=\left(v_{n}-v_{n-5}\right) / 5\right)$. Notice that the applied form factors $f$ and $f_{\mathrm{n}-5}$ depend on both current stem diameter and current tree height; thus their changes from the beginning to the end of the 5-year period are taken into consideration. 
The selected stands were not actively thinned during this period in most of the cases. Nevertheless, in the case of any removed dead trees during the period 2009-2013, the estimation of their volume growth and volume was based on the number, diameter, age of stumps, and annual size growth of the mean tree in the case of thinned trees and on the basis of the final diameter and height in 2013 in the case of dead trees.

For all steps of the evaluation minor proportions $(<10 \%)$ of other conifers were assigned to Scots pine and deciduous trees to European beech. The resulting forest stand attributes in 2009, 2013, and the growth rates in this 5 -year period were the main variables for the subsequent evaluation.

\section{Data evaluation}

\section{Nomenclature for stand evaluation}

The productivities of species 1 (Scots pine, S.pi) and 2 (European beech, E.be) in monoculture are named $p_{1}$ and $p_{2}$. The productivity of the mixed stand in total is $p_{1,2}$, the share of species 1 and 2 are $p p_{1,(2)}$ and $p p_{(1), 2}\left(p_{1,2}=\right.$ $p p_{1,(2)}+p p_{(1), 2)}$ and their mixing proportions are $m_{1}$ and $m_{2}\left(m_{1}+m_{2}=1\right)$. The calculation of the mixing proportions will be explained in the subsequent sections. The productivities per ha of species 1 and 2 in the mixed stand are called $p_{1,(2)}$ and $p_{(1), 2}$ and result from upscaling by the species-specific mixing proportions $p_{1,(2)}=p p_{1,(2)} / m_{1}$ and $p_{(1), 2}=p p_{(1), 2} / m_{2}$, respectively. As measures of productivity we used the mean period stand basal area growth $\left(\mathrm{m}^{2} \mathrm{ha}^{-1}\right.$ year $\left.^{-1}\right)$ and stand stem volume growth $\left(\mathrm{m}^{3} \mathrm{ha}^{-1}\right.$ year $\left.^{-1}\right)$ in the 5-year period 2009-2013. The evaluation for volume production is essential for management decisions and planning; however, these calculations required the reconstruction of tree height growth and assumptions about the stem form factors described above. Since the evaluation of stand basal area growth required no assumptions beyond the stand and increment core measurements, it is less prone to inaccuracy, but also less informative for forest practice.

Comparisons between mixed and pure stands with respect to other tree and stand variables as, e.g., tree size, stand volume, or stand density follow the same nomenclature and algorithm (see Pretzsch 2009, pp. 352-354).

\section{Stand density}

For quantifying the stand density and mixing proportions, tree number per unit area $\left(\mathrm{N} \mathrm{ha}^{-1}\right)$ is rather ambiguous as the mixed species may differ in current mean tree size and growing area requirement. Stand basal area $\left(\mathrm{BA} \mathrm{m}^{2} \mathrm{ha}^{-1}\right)$ is better, and the stand density index (SDI, ha ${ }^{-1}$ ) is even more informative, because it considers both tree number and size and is based on allometric theory (Pretzsch 2006; Pretzsch and Biber 2005; Reineke 1933). Reineke (1933) based his stand density index SDI $=N \times\left(25 / d_{\mathrm{q}}\right)^{-1.605}$ on the allometric relationship between tree number, $N$, and quadratic mean diameter of a stand, $d_{\mathrm{q}}$. Comparison of the SDI values of different species and calculation of a combined SDI of species in a mixed stand has to consider their species-specific growing area requirements. In this study the species-specific growing area requirement were calculated from the densities on the fully stocked pure stands of the triplets, used as references for the maximum stand densities for that site $\left(\right.$ SDIMAX $_{1}$, SDIMAX $\left._{2}\right)$. They were used to derive equivalence coefficients $e_{2 \Rightarrow 1}=$ SDIMAX $_{1} /$ SDIMAX $_{2}$ and $e_{1 \Rightarrow 2}=$ SDIMAX $_{2} /$ SDIMAX $_{1}$ for converting the SDI from one species to the other. We adapted this concept from the Lotka-Volterra approach for modelling inter-specific competition between species with different sizes and competition effects (Begon et al. 1998, pp. 177-181). The equivalence coefficients may be used to calculate a common density measure for species 1 and 2 in the mixed stand $\left(\mathrm{SDI}_{1,2}=\mathrm{SDI}_{1,(2)}+\right.$ $\left.\operatorname{SDI}_{(1), 2} \times e_{2 \Rightarrow 1}\right)$ and to make the mixed stands' density comparable to the pure stand. We used the underscore of the 1 in $\mathrm{SDI}_{1,2}$ to indicate that the combined SDI has been converted to the level of species 1. By this conversion, the stand densities of different species can be combined. The resulting $\mathrm{SDI}_{1,2}$ value may be used to calculate the relative density of the mixed stand in relation to the monoculture

$\mathrm{RD}_{1,2}=\mathrm{SDI}_{1,2} / \mathrm{SDI}_{1}$.

$\mathrm{RD}$ represents a measure for overstocking of the mixedspecies stands in relation to the neighbouring monocultures within each triplet.

\section{Mixing proportions}

Based on the total stand density standardized to species 1 $\left(\mathrm{SDI}_{1,2}=\mathrm{SDI}_{1,(2)}+\mathrm{SDI}_{(1), 2} \times e_{2 \Rightarrow 1}\right)$ and the shares of species $1\left(\mathrm{SDI}_{1,(2)} / \mathrm{SDI}_{1,2}\right)$ and $\left.2\left(\mathrm{SDI}_{(1), 2} \times e_{2 \Rightarrow 1}\right) / \mathrm{SDI}_{\underline{1,2}}\right)$, the mixing proportions $m_{1}$ and $m_{2}$ of species 1 and 2 are

$$
\begin{aligned}
& m_{1}=\mathrm{SDI}_{1,(2)} /\left(\mathrm{SDI}_{1,(2)}+\mathrm{SDI}_{(1), 2} \times \operatorname{SDIMAX}_{1} / \mathrm{SDIMAX}_{2}\right) \\
& \text { and } m_{2}=\left(\mathrm{SDI}_{(1), 2} \times \mathrm{SDIMAX}_{1} / \mathrm{SDIMAX}_{2}\right) /\left(\mathrm{SDI}_{1,(2)}\right. \\
& \left.\quad+\mathrm{SDI}_{(1), 2} \times \mathrm{SDIMAX}_{1} / \mathrm{SDIMAX}_{2}\right)
\end{aligned}
$$

For similar approaches which consider the species-specific growing space requirements for evaluation of mixing proportions see Dirnberger and Sterba (2014) and Huber et al. (2014). 


\section{Comparing mean tree characteristics}

In order to show the growth relationship between Scots pine and European beech, the mean and dominant tree characteristics in the pure stands of the triplets were compared with each other, e.g. $h_{\mathrm{q} 1}$ versus $h_{\mathrm{q} 2}, d_{\mathrm{q} 1}$ versus $d_{\mathrm{q} 2}, \ldots, h_{\mathrm{o} 1}$ versus $h_{\mathrm{o} 2}$ (top height). The ratios $\mathrm{Rh}_{\mathrm{q}}=h_{\mathrm{q} 1} / h_{\mathrm{q} 2}$, etc., quantify the relationship between both species in the pure stands. The mean ratio, $\overline{\mathrm{Rh}}_{\mathrm{q}}$, and its standard error, $\mathrm{SE}_{\overline{\mathrm{Rh}}_{\mathrm{q}}}$, over all 32 triplets provides a simple basis for testing whether the performance of the two species differs. If 1.0 is beyond the confidence interval $\overline{\mathrm{Rh}}_{\mathrm{q}} \pm t_{n-1, \alpha=0.05} \times \mathrm{SE}, \quad \overline{\mathrm{Rh}}_{\mathrm{q}} \pm \quad t_{n-1, \alpha=0.01} \times \mathrm{SE}, \quad \overline{\mathrm{Rh}}_{\mathrm{q}} \pm$ $t_{n-1, \alpha=0.001} \times \mathrm{SE}$ the differences can be considered as significant at the level $p \leq 0.05^{*}, p \leq 0.01^{* *}$, or even $p \leq 0.001^{* * *}$. Differences between species and their behaviour in mixed and pure stands were tested analogously.

\section{Comparing area related sum values such as stand basal area and standing volume}

At the whole stand level, standing volume of the mixed stand $V_{1,2}$ was compared with the weighted mean of the two pure stands $\hat{V}_{1,2}=V_{1} \times m_{1}+V_{2} \times m_{2}$. For analogous comparison at the species level, the standing volumes $V V_{1,(2)}$ and $V V_{(1), 2}\left(V_{1,2}=V V_{1,(2)}+V_{(1), 2}\right)$ in the mixed stand can be upscaled to one hectare, using the mixing proportions $m_{1}$ and $m_{2}$ and then compared with the respective pure stands $\left(R V_{1,(2)}=V V_{1,(2)} / m_{1} / V_{1}\right.$ and $\left.R V_{(1), 2}=V V_{(1), 2} / m_{2} / V_{2}\right)$.

\section{Overyielding and underyielding}

The relative productivity at the stand and species levels in the 5-year period 2009-2013 was used for deriving measures of overyielding and underyielding according to Pretzsch et al. (2010, 2013a). Firstly, we considered the relative productivity, $\mathrm{RP}_{1,2}$, between mixed-species stands and monocultures for the stands as a whole. It resulted from the observed productivity of the mixed stand $p_{1,2}$ divided by the productivity expected for the mixed stand $\hat{p}_{1,2}$

$\mathrm{RP}_{1,2}=p_{1,2} / \hat{p}_{1,2}$.

The expected productivity $\hat{p}_{1,2}$ was derived from the productivity of both species in the neighbouring pure stands, $p_{1}$ and $p_{2}$, and their mixing proportions $m_{1}$ and $m_{2}$ $\left(\hat{p}_{1,2}=m_{1} \times p_{1}+m_{2} \times p_{2}\right)$. Secondly, the relative productivity RP of species 1 and 2 in mixed versus pure stands was of interest. For species 1 the relative productivity in mixed versus pure stand was

$\mathrm{RP}_{1,(2)}=p p_{1,(2)} / m_{1} / p_{1}$,

with the share of productivity of species 1 in the mixed stand, $p p_{1,(2)}$, mixing proportion, $m_{1}$, and productivity of the pure stand, $p_{1}$. For species 2 the formula $\operatorname{RP}_{(1), 2}=$ $p p_{(1), 2} / m_{2} / p_{2}$ was applied. Notice that $p p_{1,(2)}$ and $p p_{(1), 2}$ were the contributions of the productivity of species 1 and 2 in the mixed stand which added up to $p_{1,2}\left(p_{1,2}=\right.$ $\left.p p_{1,(2)}+p p_{(1), 2}\right)$. In contrast, $p_{1,(2)}$ and $p_{(1), 2}$ were the contributions of both species in the mixed stand scaled up to 1 ha using their mixing proportion $\left(p_{1,(2)}=p p_{1,(2)} / m_{1}\right.$ and $\left.p_{(1), 2}=p p_{(1), 2} / m_{2}\right)$.

Site index and total yield as indicators for site conditions

For analysing any dependencies between overyielding or underyielding and the site fertility, we used the height of the quadratic mean diameter, $h_{\mathrm{q}}$, of Scots pine and European beech at an age of 50 and 100 years (see Pretzsch 2009, pp. 200-203 for the definition and calculation of $d_{\mathrm{q}}$; based on the quadratic mean diameter $d_{\mathrm{q}}$, the height $h_{\mathrm{q}}$ was read off the diameter-height curves). The site index was referenced or extrapolated from yield tables by Wiedemann (1943) and Schober (1967) for Scots pine and European beech.

Even when tree height and age are similar the total yield can vary between stands on different sites because of different yield levels (Assmann 1970, p. 167). So, total yield at a reference age may provide a better indication of the productivity at the 32 sites than the site index. The total merchantable stem volume yield $\geq 7 \mathrm{~cm}$ over bark at age 50 years (Y50) was used as an indicator for stand productivity for quantifying how overyielding depends on sitespecific productivity. We derived Y50 for all stands of pure Scots pine and European beech from the commonly used yield tables for these species in the respective countries and regions. So, both mean stand height and total volume yield at age 50 years were available for subsequent statistical analysis of relationships between mixing effects and site characteristics.

We further used the Martonne index (1926) $(M=$ annual precipitation $(\mathrm{mm}) /($ mean annual temperature $\left.\left.\left({ }^{\circ} \mathrm{C}\right)+10\right)\right)$ for characterizing the water supply at the 32 sites (see Supplement Table 1). The higher the Martonne index, the better the water supply for plant growth; the lower this index, the stronger the likelihood of drought. This index has been widely used in recent studies to describe the drought condition or aridity in a given region (Quan et al. 2013). We used the index of Martonne because of its minimal data requirement.

\section{Statistical analysis and models}

We used the OLS-linear regression algorithm for analysing any relationships between the overyielding and overdensity at the stand level in relation to independent variables such as stand and site characteristics [mixing proportion, stand 
productivity, site index, precipitation, temperature, Martonne index (1926) etc.]. All calculations were carried using the software package IBM SPSS Statistics (Version 22).

\section{Results}

Because of a 149-year-old triplet in the Ukraine the mean age given in Table 1 is 69 and 70 years, however, in most cases the stand age ranged between 40 and 60 years. Therefore, we used the top height, $h_{\mathrm{o}}$, and the height associated with the quadratic mean diameter, $h_{\mathrm{q}}$, at age 50 to characterize the variation between the triplets regarding their height growth. Top height of Scots pine at age 50 years ranges between $h_{\mathrm{o}}=9.5-26.9 \mathrm{~m}$ and quadratic mean height between $h_{\mathrm{q}}=8.9-25.8 \mathrm{~m}$. For European beech the respective values are $h_{\mathrm{o}}=11.7-27.6$ and $h_{\mathrm{q}}=9.4-25.9 \mathrm{~m}$. This wide variation in stand height at age 50 years indicates the wide range of site conditions represented by the set of 32 triplets in different parts of Europe.

Notice that Table 1 shows the characteristics for the mixed stand in total and the share of both species, i.e., the mean standing volume of the Scots pine/European beech mixed stands amounts to $444 \mathrm{~m}^{3} \mathrm{ha}^{-1}$, the shares of Scots pine and European beech are, on average, 255 and $189 \mathrm{~m}^{3} \mathrm{ha}^{-1}$, respectively.

Because of the broad variation of site quality and stand age, the range of all stand characteristics was very wide (Table 1). Figure 3a-d uses the pure stands to illustrate that the triplets cover a very wide range of stand growth performance, e.g. mean height ranges between 10 and $35 \mathrm{~m}$ and periodic annual volume growth (PAIV) between 5 and $25 \mathrm{~m}^{3} \mathrm{ha}^{-1}$ year $^{-1}$. Regarding mean height, pure European beech stands are on average about $10 \%$ ahead of pure stands of Scots pine. The triplets cover the age phase where the early-successional and fast-growing Scots pine begins to lose its height advantage and is eventually overtopped by the late successional, initially slower but later faster
Fig. 3 Growth and yield of Scots pine ( $x$-axis) compared to European beech ( $y$-axis) in the pure stand plots of the 32 triplets. Values on the bisector line indicate equality of the pure stand characteristics of both species. a Quadratic mean height, $h_{\mathrm{q}}(\mathrm{m})$, b stand density index, SDI (tree ha ${ }^{-1}$ ),

c standing merchantable $(>7 \mathrm{~cm}$ at the smaller end) stem volume, $V\left(\mathrm{~m}^{3} \mathrm{ha}^{-1}\right)$, and $\mathbf{d}$ mean periodic increment of the stand volume, PAIV

$\left(\mathrm{m}^{3} \mathrm{ha}^{-1}\right.$ year $\left.{ }^{-1}\right)$, during the 5 years before the stand inventory. The small symbols represent the observed values and the large symbols indicate the mean values of all 32 triplets (a)

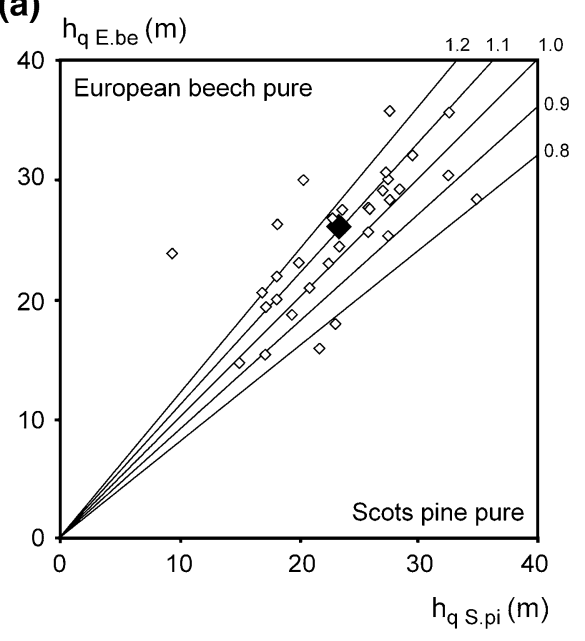

(c)

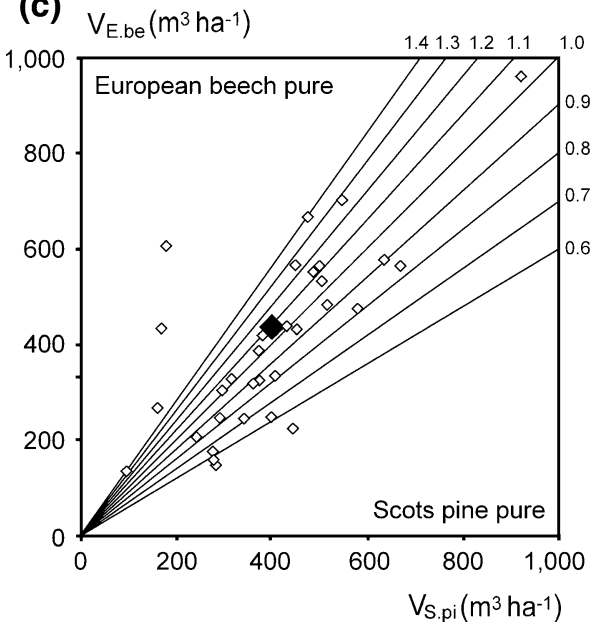

(b)

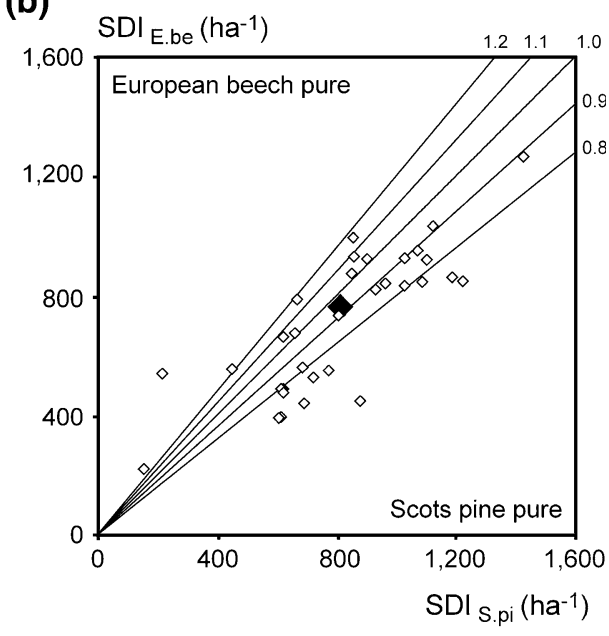

(d)

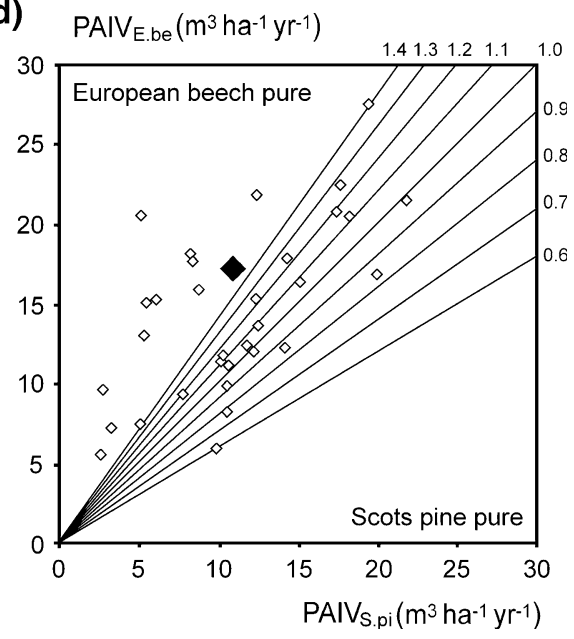


growing European beech. SDI is about $5 \%$ lower in pure beech than in pure pine stands. Despite lower SDI, the higher form factor of beech results in a $10 \%$ higher standing volume of pure beech compared with pure pine stands. PAIV is about $50 \%$ higher in pure beech compare to pine stands (Fig. 3a-d).

\section{Stand productivity and density of mixed versus pure stands}

Figure 4a-d, shows higher SDI, standing volume, stand basal area growth, and stand volume growth, in mixed compared with pure stands. Table 2 reveals that the SDI is on average about $20 \%$ higher in mixed compared to the weighted mean of the neighbouring pure stands. Both species contribute equally to this superiority. In other words, fully stocked mixed stands at an age of 60-80 years can carry about $100-150$ trees or $100-150 \mathrm{~m}^{3} \mathrm{ha}^{-1}$ more than pure stands. The mean periodic increment of stand basal area and stem volume in the last 5 years lie about 12 and $8 \%$ above the weighted mean of the pure stands, respectively. In terms of the volume growth, this is equivalent to an overyielding of $1-2 \mathrm{~m}^{3} \mathrm{ha}^{-1}$ year $^{-1}$. The results for the stand basal area growth indicate that there is a significant overyielding for the whole stand, mainly caused by the higher growth of European beech in mixed compared to pure plots $\left(\mathrm{RP}_{(1), 2}=1.25\right)$. In contrast, the basal area growth of Scots pine is similar in monoculture and mixed-species stands. However, in terms of volume growth, the two species contributed similarly.

The mean of the PAIV amounts to $11.0 \mathrm{~m}^{3} \mathrm{ha}^{-1}$ year $^{-1}$ in pure Scots pine and $14.7 \mathrm{~m}^{3} \mathrm{ha}^{-1}$ year $^{-1}$ in pure European beech (Table 1). The corresponding PAIV of $13.6 \mathrm{~m}^{3} \mathrm{ha}^{-1}$ year ${ }^{-1}$ in the mixed stands indicated that on average there is no transgressive overyielding (mixed stand growth $>$ growth of pure stand of species 1 and 2) of the mixed stands over the two pure stands of Scots pine and European beech, respectively.
Fig. 4 Characteristics of the expected ( $x$-axis, weighted mean of the neighbouring pure stands) and observed (y-axis) growth and yield of mixed stands of Scots pine and European beech. Values on the bisector line indicate equality of observed and expected mixed stand characteristics. Values above the line indicate higher stand density, standing volume, and mean periodic stand growth of mixed compared with pure stands. a Expected stand density index, $\hat{S D I}_{\text {S.pi, E.be, compared }}$ with observed stand density index, $\mathrm{SDI}_{\mathrm{S} \text {.pi,E.be }}$ (the underline in $\mathrm{SDI}_{\text {S.pi, E.be }}$ indicates that the SDI was standardized to species $1=$ Scots pine). $\mathbf{b}$ Expected standing stem volume, $\hat{V}_{\text {S.pi, E.be }}$ $\left(\mathrm{m}^{3} \mathrm{ha}^{-1}\right.$, of merchantable stem volume $\geq 7 \mathrm{~cm}$ over bark) versus observed volume,

$V_{\text {S.pi,E.be }} \cdot \mathbf{c}, \mathbf{d}$ Expected growth of stand basal area,

PAIBA $_{\text {S.pi,E.be }}\left(\mathrm{m}^{2} \mathrm{ha}^{-1}\right)$, and tree volume, $\hat{P A I V}$ S.pi, E.be $\left(\mathrm{m}^{3} \mathrm{ha}^{-1}\right)$, compared with the observed growth of stand basal area, PAIBA $A_{\text {S.pi, E.be }}\left(\mathrm{m}^{2} \mathrm{ha}^{-1}\right)$, and tree volume, PAIV $V_{\text {S.pi,E.be }}$ $\left(\mathrm{m}^{3} \mathrm{ha}^{-1}\right)$, during the last 5 years before stand inventory

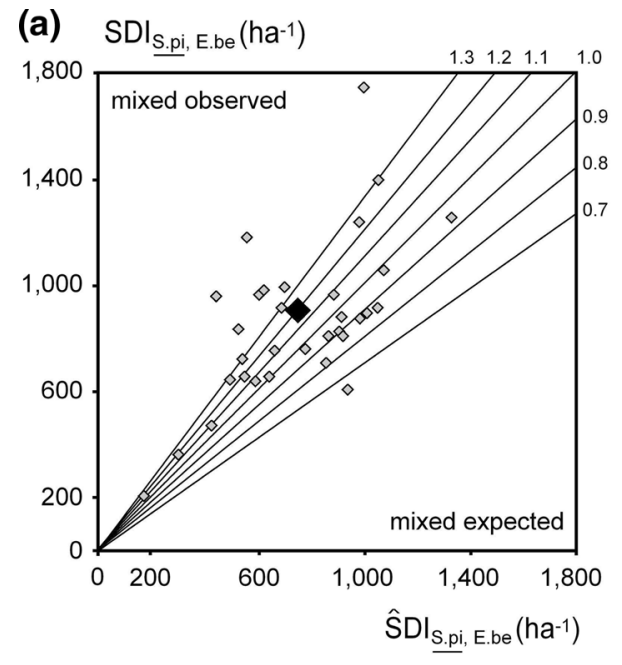

(c) PAIBA ${ }_{\text {s.pi, E.be }}\left(\mathrm{m}^{2} \mathrm{ha}^{-1} \mathrm{yr}^{-1}\right)$

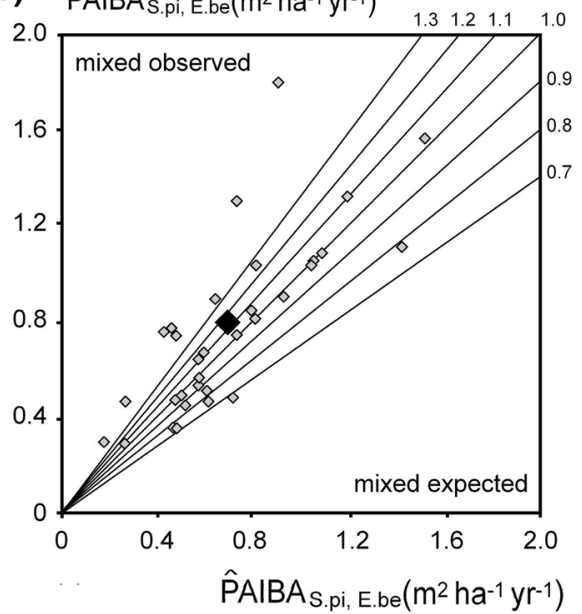

(b) $V_{\text {S.pi Ebe }}\left(m^{3} h^{-1}\right)$

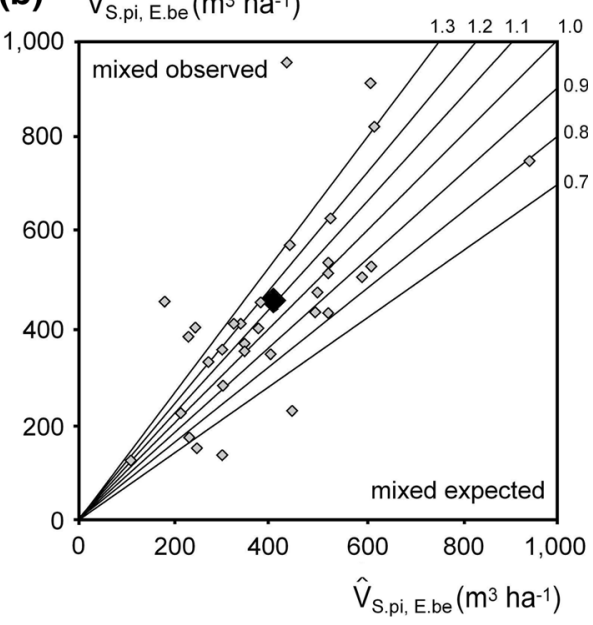

(d)

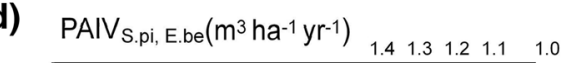

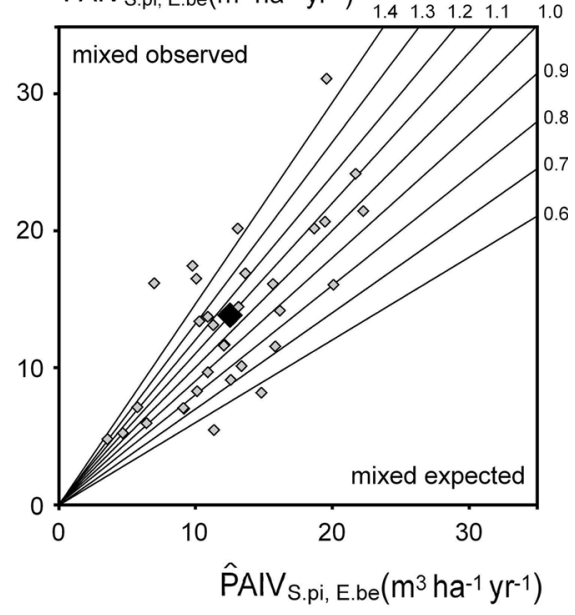


Table 2 Descriptive statistics (mean $\pm \mathrm{SE}$ ) for the relationship between the observed mixed stand (obs) against the expected (exp) mixed stand and tree species in pure stand (p) against the corresponding species in the mixed stand (m)

\begin{tabular}{|c|c|c|c|c|c|c|}
\hline \multirow[t]{2}{*}{ Stand variable } & \multicolumn{2}{|c|}{ Mixed $_{\text {obs }} /$ Mixed $_{\text {exp }}$} & \multicolumn{2}{|c|}{ S.pine $_{m} /$ S.pine $e_{p}$} & \multicolumn{2}{|c|}{ E.beech $_{\mathrm{m}} /$ E.beech $_{\mathrm{p}}$} \\
\hline & Mean & $\mathrm{SE}( \pm)$ & Mean & $\mathrm{SE}( \pm)$ & Mean & $\mathrm{SE}( \pm)$ \\
\hline$N\left(\right.$ trees $\left.\mathrm{ha}^{-1}\right)$ & 1.14 & 0.07 & 0.93 & 0.08 & 1.35 & 0.09 \\
\hline$d_{\mathrm{q}}(\mathrm{cm})$ & & & 1.20 & 0.05 & 0.92 & 0.03 \\
\hline$d_{\mathrm{o}}(\mathrm{cm})$ & & & 1.15 & 0.04 & 0.96 & 0.03 \\
\hline$h_{\mathrm{q}}(\mathrm{m})$ & & & 1.06 & $\mathbf{0 . 0 3}$ & 0.92 & $\mathbf{0 . 0 3}$ \\
\hline$h_{\mathrm{o}}(\mathrm{m})$ & & & 1.05 & 0.03 & 0.94 & $\mathbf{0 . 0 3}$ \\
\hline$h_{\mathrm{q}} / d_{\mathrm{q}}$ & & & 0.92 & $\mathbf{0 . 0 3}$ & 1.01 & 0.03 \\
\hline$h_{\mathrm{o}} / d_{\mathrm{o}}$ & & & 0.94 & $\mathbf{0 . 0 3}$ & 0.99 & 0.03 \\
\hline BA $\left(\mathrm{m}^{2} \mathrm{ha}^{-1}\right)$ & 1.12 & 0.06 & 1.17 & 0.07 & 1.05 & 0.06 \\
\hline$V\left(\mathrm{~m}^{3} \mathrm{ha}^{-1}\right)$ & 1.12 & 0.08 & 1.25 & 0.08 & 0.99 & 0.08 \\
\hline SDI (trees ha ${ }^{-1}$ ) & 1.20 & 0.06 & 1.11 & 0.06 & 1.11 & 0.06 \\
\hline PAIBA $\left(\mathrm{m}^{2} \mathrm{ha}^{-1}\right.$ year $\left.^{-1}\right)$ & 1.12 & 0.06 & 0.97 & 0.07 & 1.25 & 0.08 \\
\hline $\operatorname{PAIV}\left(\mathrm{m}^{3} \mathrm{ha}^{-1}\right.$ year $\left.^{-1}\right)$ & 1.08 & 0.07 & 1.10 & 0.06 & 1.09 & 0.07 \\
\hline
\end{tabular}

Variables listed include trees per hectare, $N$, quadratic mean diameter, $d_{\mathrm{q}}$, top diameter, $d_{\mathrm{o}}$, quadratic mean height, $h_{\mathrm{q}}$, top height, $h_{\mathrm{o}}$, relation between $d_{\mathrm{q}}$ and $h_{\mathrm{q}}$ and $d_{\mathrm{o}}$ and $h_{\mathrm{o}}$, basal area $(G)$ and volume $(V)$ of the remaining stand, stand density index (SDI), periodic annual basal area (PAIBA) and volume (PAIV) increment

Bold values indicate significant differences between mixed and pure stands at least at the level $p \leq 0.05$

\section{Mean size growth of Scots pine and European beech in mixed versus pure stands}

The relationships between the mean tree characteristics in mixed compared with pure stands shown in Fig. 5 reflect how the intra-specific behaviour is modified by decades of inter-specific interactions. In mixed stands mean height of pine is $6 \%$ higher and mean diameter is $20 \%$ higher than in pure stands, so that the ratio between $h_{\mathrm{q}} / d_{\mathrm{q}}$ is $8 \%$ lower in mixed compared with pure stands (Fig. 5a, c, e; Table 2). In contrast, mean height and mean diameter of European beech are $8 \%$ lower in mixture and the mean $h_{\mathrm{q}}$ l $d_{\mathrm{q}}$ is $2 \%$ higher in mixed versus pure stands. Due to the superior height of Scots pine, the growth of beech was reduced and modified towards growth partitioning in favour of height compared with diameter growth (Fig. 5b, $\mathrm{d}, \mathrm{f}$; Table 2). It is probably the superiority of Scots pine which causes inter-specific competition and slows growth of European beech in mixed compared to pure stands. As a result of this dominance of Scots pine, the ratio $h_{\mathrm{q}} / d_{\mathrm{q}}$ is 71 in mixed compared to 80 in pure stands. The $h_{\mathrm{q}} / d_{\mathrm{q}}$ ratio of European beech is 93 in mixed versus 91 in pure stand.

\section{Spatial variation of mixing effects along the productivity gradient}

We used an extensive set of stand and site characteristics and tested their effect on overyielding regarding volume productivity, PAIV, by linear regression. We also combined several different site and stand characteristics in multiple linear regression.
As a site variable we applied the mean height of the pure Scots pine stand and pure European beech stand at age 50 years (site index). We further used the stand productivity of the pure stands, their yield according to common yield tables and growth models, the local climate variables mean annual temperature, annual precipitation, and their combination in the Martonne index (1926). As stand variables we used the mixing proportion, the ratio between the mean height of Scots pine and European beech in the mixed stand, and the stand density of the mixed stand.

We could not find any statistically significant relationships between the site variables and the overyielding in terms of PAIV. Due to space restrictions, we only show the relationship between the relative volume productivity and the mean stand height at age 50 years (Fig. 6a-c) and between the relative productivity and the Martonne index (Fig. 6d-f). In no cases did we find any significant effect of site index, productivity, yield, climate variables, mixing proportions or age on the overyielding at stand or species level (Table 3). We calculated an extensive set of univariable and multiple-variable regressions with site and stand variables in various combinations and transformations, but there were no significant influences left except $\mathrm{RD}$. The 149-year-old triplet in the Ukraine is much older than the other triplets, may be an outlier, and distorted the analysis. However, omitting this data from the analysis did not change the results.

The relative stand productivity, $\mathrm{RP}_{1,2}$ (i.e., the overyielding in mean annual stand volume growth and stand basal area growth) increased significantly with the relative stand 
Fig. 5 Stand characteristics of Scots pine (triangles) and European beech (circles) in the pure stands ( $x$-axis) compared with the neighbouring mixed stands ( $y$-axis). Values on the bisector line indicate equality of mixed with pure stand characteristics. a, b Mean height, $h_{\mathrm{q}}(\mathrm{m})$, of Scots pine and European beech, respectively. c, d Quadratic mean diameter, $d_{\mathrm{q}}(\mathrm{cm})$, of Scots pine and European beech, respectively. e, f Ratios between mean height and mean diameter, $h_{\mathrm{q}} / d_{\mathrm{q}}$ $\left(\mathrm{m} \mathrm{cm}^{-1}\right)$ for Scots pine and European beech, respectively. The small symbols represent the observed values and the large symbols indicate the mean values of all 32 triplets
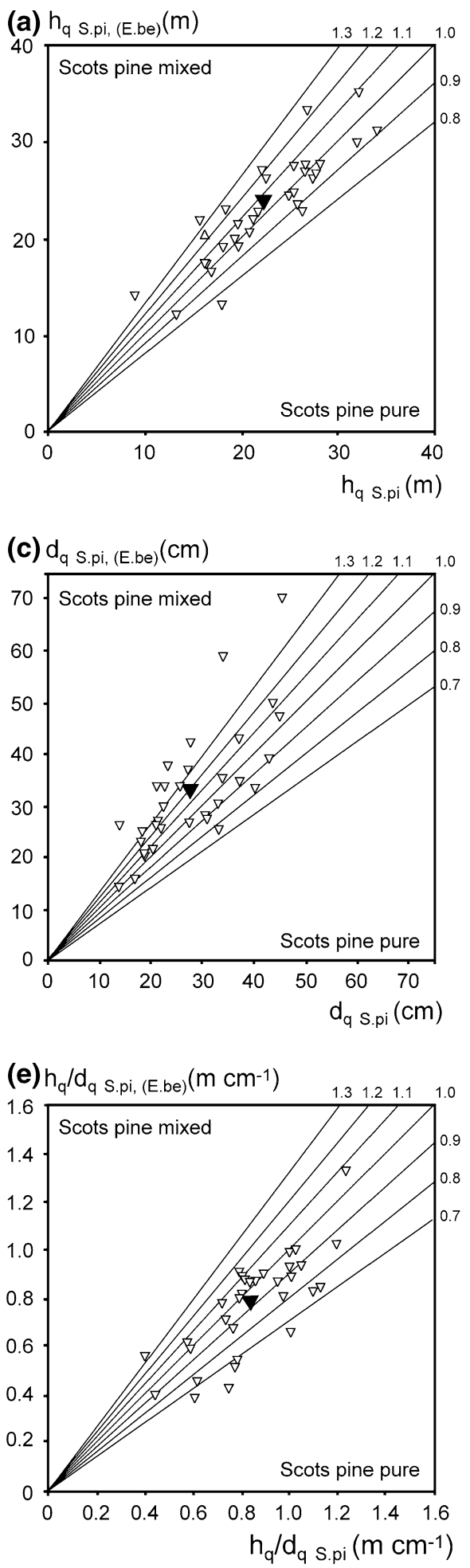
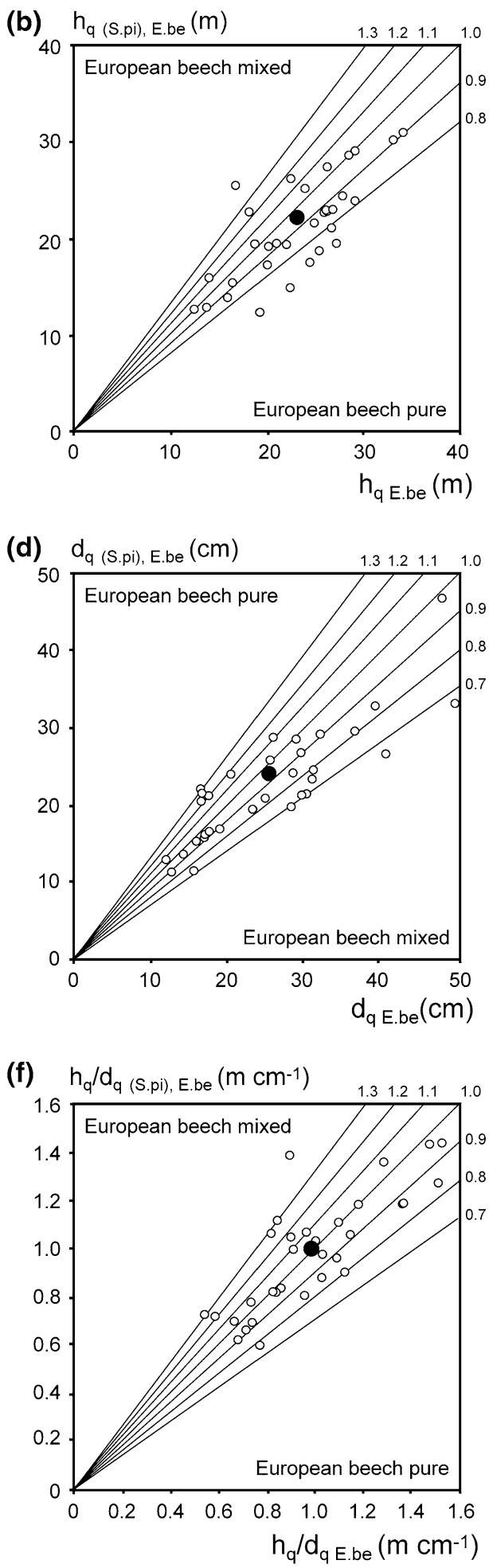

density, $\mathrm{RD}_{1,2}$ (i.e., the ratio between the SDI of the mixedspecies stands and monocultures). Figure 7 shows the observed productivities on the 32 triplets. The straight line was fitted by linear OLS regression to the observations
$\left(\mathrm{RP}_{1,2}=0.08( \pm 0.18)+0.90( \pm 0.15) \times \mathrm{RD}_{1,2}, \quad n=32\right.$, $\left.R^{2}=0.54, p<0.001\right)$. The model equation reveals that the intercept does not deviate significantly from 0 ; thus, $\mathrm{RP}_{1,2}$ increases proportionally to the relative stand density, $\mathrm{RD}_{1,2}$. 
(a)

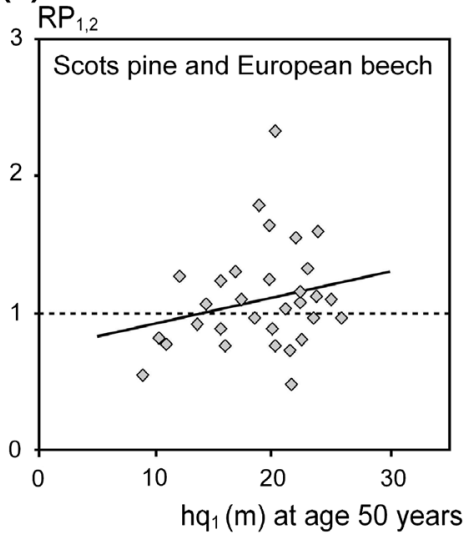

(d)

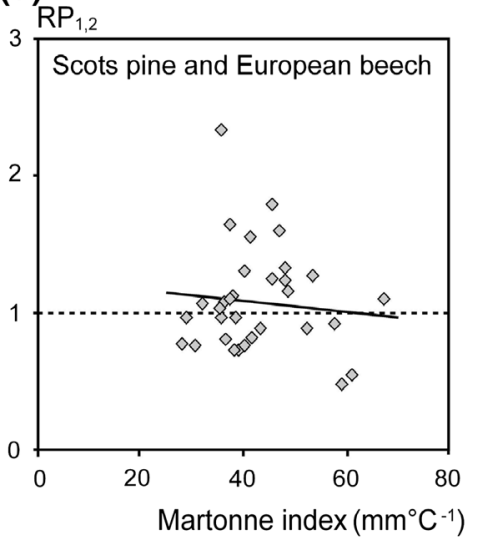

(b)

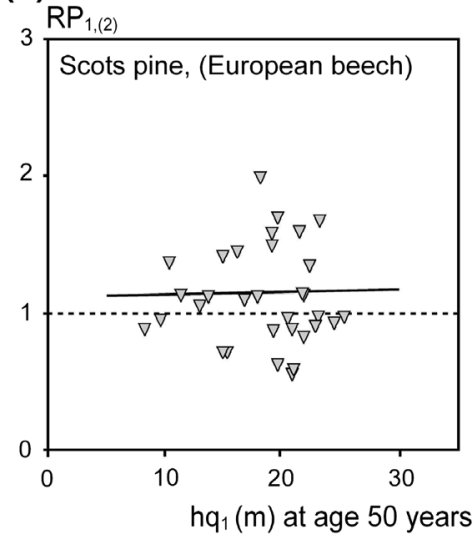

(e)

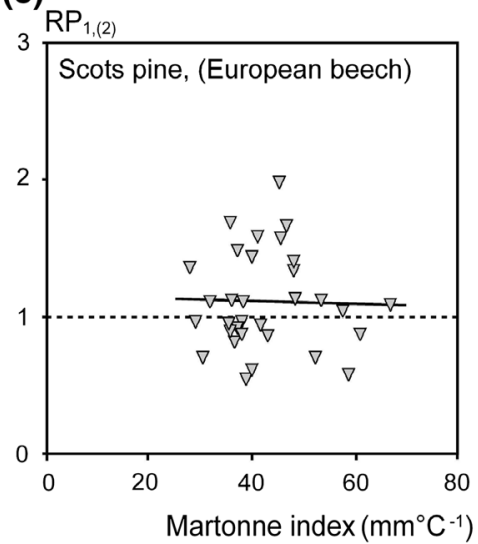

(c)

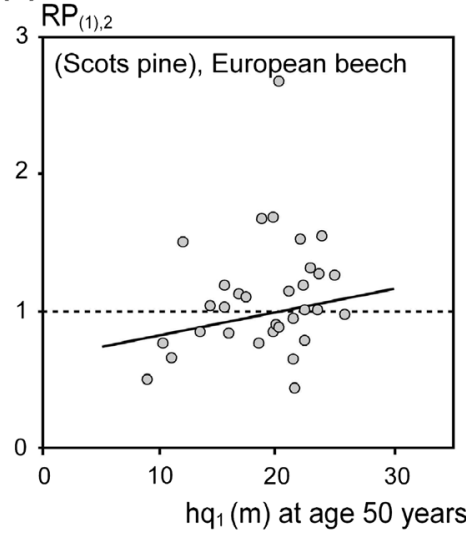

(f)

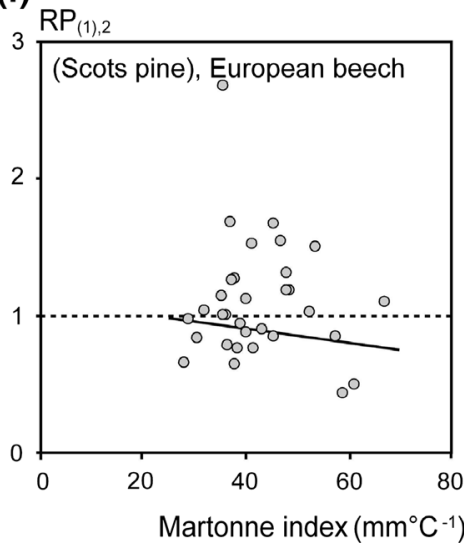

Fig. 6 Relative stand volume productivity, RP, at the total stand level, $\mathrm{RP}_{1,2}$, and at the species level, $\mathrm{RP}_{1,(2)}$ and $\mathrm{RP}_{(1), 2}$, on the 32 triplets plotted against $\mathbf{a}, \mathbf{b}, \mathbf{c}$ the mean stand height of Scots pine at age 50, $h_{\mathrm{q} 1}$, and $\mathbf{d}, \mathbf{e}, \mathbf{f}$ the Martonne index (1926). Analyses of these relationships by linear OLS regression yielded the added straight lines which showed in no case a significant $(p<0.05)$ change in overyielding depending on the growing conditions (see Table 3 )
Table 3 Statistical characteristics of the relationship between overyielding at the stand level, $\mathrm{RP}_{1,2}$, and at the species level, $\mathrm{RP}_{1,(2)}$, resp. $\mathrm{RP}_{(1), 2}$, and variables used to characterize site productivity, $h_{\mathrm{q} 1}$, and Martonne index

\begin{tabular}{lllllll}
\hline Variable & $n$ & Intercept & $h_{\mathrm{q} 1}$ at age 50 & Martonne index & $R^{2}$ & $p$ \\
\hline $\mathrm{RP}_{1,2}$ & 32 & $0.73 \pm 0.30$ & $0.019 \pm 0.015$ & & 0.02 & $<0.23$ \\
$\mathrm{RP}_{1,(2)}$ & 32 & $1.11 \pm 0.28$ & $0.001 \pm 0.015$ & & 0.01 & $<0.99$ \\
$\mathrm{RP}_{(1), 2}$ & 32 & $0.65 \pm 0.33$ & $0.023 \pm 0.017$ & & 0.03 & $<0.18$ \\
$\mathrm{RP}_{1,2}$ & 32 & $1.24 \pm 0.32$ & & $-0.004 \pm 0.007$ & 0.01 & $<0.63$ \\
$\mathrm{RP}_{1,(2)}$ & 32 & $1.15 \pm 0.30$ & & $-0.001 \pm 0.007$ & 0.01 & $<0.87$ \\
$\mathrm{RP}_{(1), 2}$ & 32 & $1.31 \pm 0.36$ & & $-0.005 \pm 0.008$ & 0.01 & $<0.55$
\end{tabular}

Model equation is $\mathrm{RP}_{1,2}=a+b \times$ site variable

$h_{\mathrm{q} 1}$ at age 50 represents the mean height on the pure Scots pine plot at age 50. The Martonne index, $M=$ annual precipitation $(\mathrm{mm}) /\left(\right.$ mean annual temperature $\left.\left({ }^{\circ} \mathrm{C}\right)+10\right)$ (see de Martonne 1926$)$

\section{Discussion}

Our main findings on how mixing modifies the stand dynamics of mixed versus pure stands are shown schematically in Fig. 8. The broken vertical lines present the stand development of the 32 triplets. The findings for this point in time are set into the context of the long-term stand development.
Figure 8a shows distinct differences in the diameter development of the early-successional and light demanding Scots pine and the late-successional and shade tolerant European beech. In both pure and mixed stands Scots pine has a faster early growth rate than European beech. However, beech is faster growing in the long term and reaches higher maximum sizes. In mixed stands mean diameter and height of Scots pine is accelerated, while both diameter and 


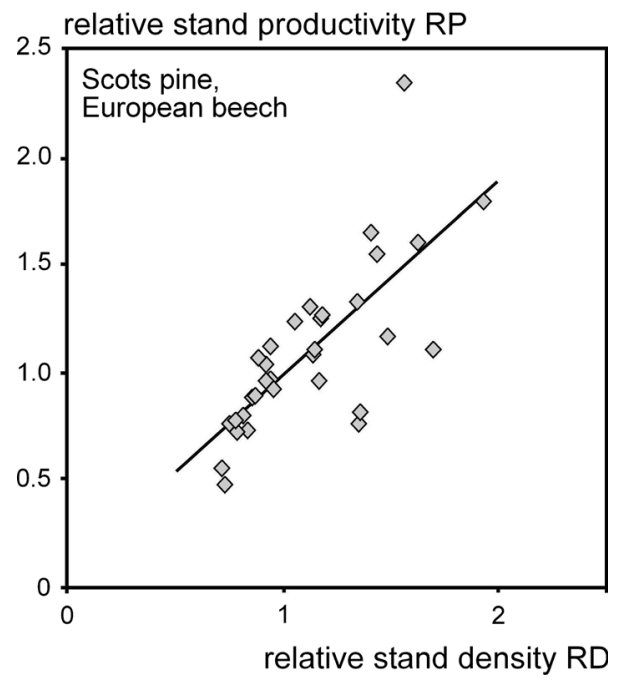

Fig. 7 Increase in relative volume productivity, $\mathrm{RP}_{1,2}$, with the relative stand density, $\mathrm{RD}_{1,2}$. Observed productivities on the 32 triplets and straight line fitted by linear OLS regression to the observations $\left(\mathrm{RP}_{1,2}=0.08( \pm 0.18)+0.90( \pm 0.15) \times \mathrm{RD}_{1,2}, n=32\right.$, $\left.R^{2}=0.54, p<0.001\right) . \mathrm{RP}_{1,2}$ represents the ratio between the periodic annual volume growth in the 5-year period 2009-2013 in the mixed stand and the weighted mean productivity of the two neighbouring pure stands. $\mathrm{RD}_{1,2}$ represents the ratio between stand density index of the mixed and the weighted mean stand density of the neighbouring pure stands

height growth of European beech are slightly slowed down, probably because of the superiority of Scots pine during the first decade of stand development. Stand productivity of the mixed stand is superior to the weighted mean productivity of the neighbouring pure stands (Fig. 8b). Total yield and standing volume are higher in the mixed stand of Scots pine and European beech compared with the weighted mean yield and standing stock of the neighbouring pure stands (Fig. 8c). The SDI is $20 \%$ higher in mixed compared with pure stands, i.e., the carrying capacity is increased by tree species mixing (Fig. 8d).

The mean overyielding found in the triplets agrees with studies at lower spatial scales where the productivity of pine-beech mixtures was generally greater than respective pure stands (Condés et al. 2013). European beech clearly benefited from the admixture of Scots pine, reflecting the advantage taken by this species when growing in mixed stands due to its low self-tolerance (Metz et al. 2013; Pretzsch and Biber, 2005), also reported for other species admixtures (Pretzsch et al. 2010, 2013a). For Scots pine the positive mixing effect is not so strong and was only significant for the stand density index. Condés et al. (2013) found that the positive effect of European beech on pine growth decreased with stand density, being very low at full stocking degrees as in our triplets. However, despite of the mean overyielding, there was a large variability in relative productivity among triplets (Fig. 4). This fact highlights the complexity of species interactions, which depend on stand development stage, stand density, and site conditions (Forrester 2014), showing in some cases opposite patterns between the same mixed species.

It is interesting that the detected increase in carrying capacity and associated overyielding does not necessarily mean larger tree sizes (Table 2). The higher stocking degrees in mixed plots may be due to larger tree sizes for pine, but for beech it seems to be related to a higher number of trees because the mean tree size is significantly lower in mixed plots. This shows that species interactions identified at tree level cannot be directly up-scaled to the stand level (Perot and Picard 2012). Studies based on individual tree growth analysis are frequent (e.g. Pretzsch and Schütze 2009; Río et al. 2014a). However, the main problem with individual tree growth results is that they often do not consider stocking density. Thus, a result in terms of "mean" tree behaviour might be biased if the density of the stand is different. So, analyses based on individual tree growth need to consider, stand density, tree mortality, or even ingrowth, to correctly infer the mixed stands dynamic (Zhao et al. 2006).

\section{Analysing overyielding and overdensity in dependence on site conditions: methodological aspects}

Experiments following replacement series (Kelty 1992) are probably the more robust way to identify mixing effects at the stand level. However, for stands of long-lived tree species, they are scarce because very long periods of monitoring would be needed. Other studies used inventory data to study mixing effects (del Río and Sterba 2009; Vallet and Perot 2011), but this approach does not necessarily compare pure and mixed stands at the same site, although site quality descriptors were included in their models. In this study we based our evaluation on 32 triplets with pure and mixed-species stands just beside each other on similar sites. This allowed us to reveal overyielding in Scots pine-European beech mixed stands directly from empirical data.

To examine relationships between site conditions and overyielding, we used the site index of the pure stands as a measure of site quality and fertility. However, stand height represents only the vertical aspect of stand productivity; even stands with equal height and age may vary considerably in yield, i.e., in the horizontal packing density. Therefore, we consulted all participants of the COST action FP1206 EuMIXFOR about the total yield at age 50 years, based on the most suitable yield table in order to get an integrated measure of both aspects of yield, height and density. The information was based on very different models, yield tables from the 1920s and 1940s, recently 
(a) tree diameter $(\mathrm{cm})$

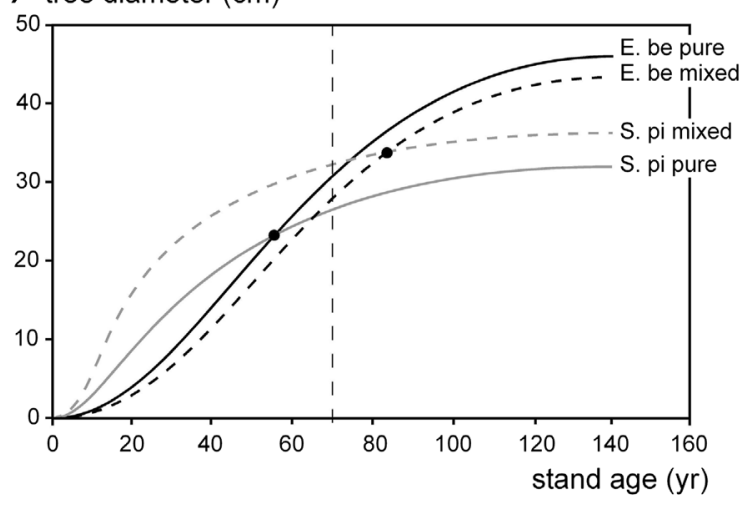

(c) total yield, standing stock $\left(\mathrm{m}^{3} \mathrm{ha}^{-1}\right)$

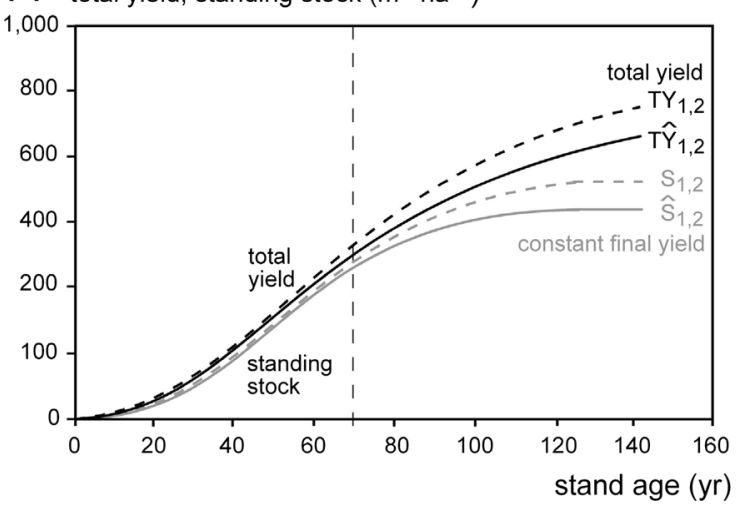

(b)

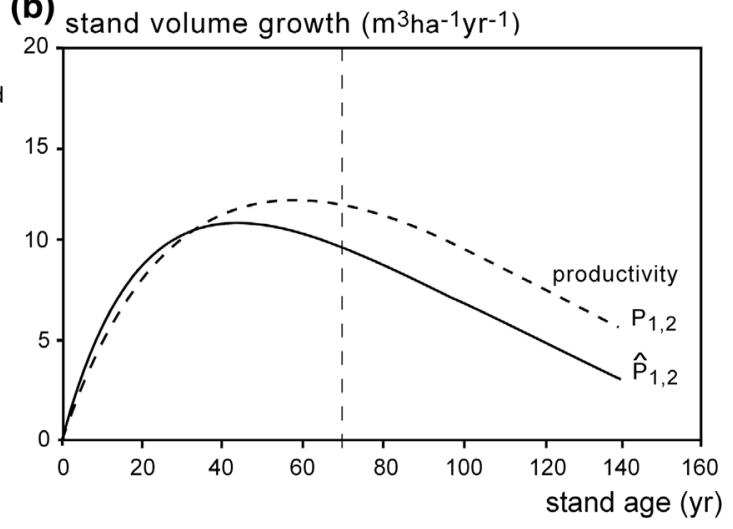

(d) tree number $\mathrm{N}\left(\mathrm{ha}^{-1}\right)$

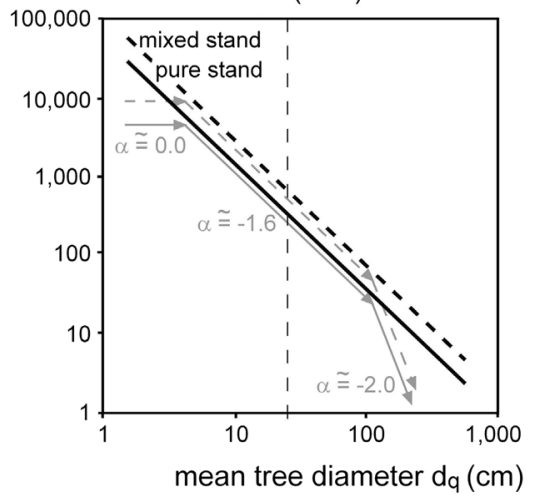

Fig. 8 Assumption of the long-term development of mixed-species stands of Scots pine and European beech compared with monocultures and representation of the mixing effects at age 70 . Trajectories for pure stands are represented by solid lines, development of mixed stands by broken lines. The broken vertical line indicates the mean age and tree size, respectively, for the 32 triplets. a Tree size development of Scots pine is accelerated in mixture with European

parameterized tables, stand simulators, and on tables barely suitable for the respective stands (e.g. from neighbouring countries). Older yield tables probably considerably underestimate the yield, while newer tables are closer to the real growth and yield levels. The use of this rather inconsistent data was questionable, so we tested three site quality indicators: mean stand height at age 50 of the pure stands, productivity of the pure stands, and the Martonne index (1926). Nevertheless, the overyielding as well as the overdensity was independent of the total yield of stem volume of the stand at age 50 years, the site index, the stand growth and yield, and climatic variables. This invariance of overyielding despite of the wide variation of precipitation $\left(520-1175 \mathrm{~mm}\right.$ year $\left.^{-1}\right)$, temperature $\left(6-10.5^{\circ} \mathrm{C}\right)$, and the Martonne index $(28-61)$ on the sites (see Supplement Table 1) was remarkable. These results as well as the lack of relationship between relative productivity and other stand characteristics highlight the complexity of species interactions. Competition, complementarity, and facilitation depend on many factors such as beech, while the size development of European beech is slowed down compared with the neighbouring pure stands. b The volume productivity exceeds the weighted mean productivity of the neighbouring pure stands by $8 \%$. c The yield and standing stock is $12 \%$ higher in the mixed stand compared with the neighbouring pure stands. d The stand density, quantified by the SDI, is $20 \%$ higher in mixed compared with pure stands

stand developmental stage, stand density, and site conditions (Forrester 2014), and possibly also interactions between these factors that require further studies (Pretzsch et al. 2015).

One methodological aspect which could have influenced our results is the approach of estimating the species proportions on the mixed plots. Recent studies demonstrated the influence of species proportion definition on the magnitude of identified overyielding/underyielding (Dirnberger and Sterba 2014; Huber et al. 2014). In these studies the recommended definition is the species proportion by area, where the reference is the area each species would occupy in a fully stocked pure stand, which required the use of maximum site occupancies in pure stands. The lack of knowledge of the maximum density value for each species and site along our transect of triplets made us assume that the fully stocked pure stands represent the maximum density. This to some extent might influence the observed over/underyielding as well as the stand density index values in mixed plots (Pretzsch et al. 2015). 


\section{Causes of the overyielding of mixed versus pure stands}

Equal productivity at the stand level does not necessarily indicate neutral behaviour of the mixed plants, since mixing reactions at the species, individual or organ level can counteract and cancel each other with respect to stand-level productivity (Pretzsch et al. 2010). However, behind overyielding or underyielding of mixed compared with neighbouring pure stands as revealed in this study for Scots pine and European beech is always a modified supply, capture, or use efficiency of resources (Binkley et al. 2004; Forrester 2014; Richards et al. 2010).

In the following we hypothesize which mechanisms might cause overyielding of both Scots pine and European beech in the mixture. We did not measure any eco-physiological processes. However, the growth responses at the species level, the mean tree level, the stand level, and along the ecological gradient provide indicators and statistical relationships for the underlying mechanisms and causes. So, the presented causal explanations are not mere speculation. By mixing Scots pine and European beech, all three components of resource conditions (supply, capture, or use efficiency of resources) could be improved and contribute to the overyielding.

An indication of the improved resource supply, or capture or use efficiency, is the by $20 \%$ higher maximum stand density in mixed compared with pure stands. It means that trees do not only grow quicker due to a higher turnover of the available stock of resources, but there are also more trees able to survive, because of an increased carrying capacity. A denser and deeper reaching rooting system in mixture found by Bonnemann (1939, pp. 40-43), extended humus layer reported by Heinsdorf (1999) and Knapp (1991), and an increased stock of nutrients stock found by von Mammen et al. (2003) suggest the potential for an increased supply of water and nutrients by more complete below ground exploitation and storage. Supposing, that pure pine stands are often more impoverished, poor in nutrients, and dry, Scots pine is probably the main beneficiary in terms of additional resource supply and growth, while beech is the benefactor.

When comparing the impacts of evergreen gymnosperm and deciduous angiosperm tree species on forest functioning, it appears that the former tend to promote larger inputs of elements to the soil-plant system through increased atmospheric deposition and weathering of soil minerals, while the latter are associated to a higher element nutrient recycling (Augusto et al. 2015). Assuming nutrient availability is limiting in all sites of the gradient, these contrasting nutrient cycling strategies could partly explain the observed sustained complementarity effects in the mixed-species stands compared to the corresponding pure stands.
The overyielding may also result from light-related interactions. As assumed in Fig. 8, the diameters of Scots pine were probably larger than those of beech during the early stages of development. A similar pattern occurred for the tree height. Therefore, during the early stages of stand development light-use efficiency of the mixtures could have been increased by the faster growing pine trees, compared with the beech monocultures. At the same time, the light that penetrated the pine canopies could have been absorbed by the beech trees to increase the total light absorption of the mixtures compared with the pine monocultures, while light intensity under beech canopies is only $1-2 \%$ of above canopy light availability, it is $15 \%$, i.e., about tenfold, under Scots pine (Ellenberg and Leuschner 2010 , p. 89). Combinations of high light-use efficient species with more shade tolerant species capable of high light absorption have been shown to increase light-use efficiency and light absorption of mixtures compared with monocultures (Kelty 1992; Binkley et al. 1992; Forrester et al. 2012). This may also explain the higher carrying capacity in terms of beech density in mixed plots, probably linked to lower mortality rates, since beech tree mortality is mainly due to competition for light (Monserud and Sterba 1999; Ruiz-Benito et al. 2013).

The crown architectures in terms of the relationships between tree diameter and crown diameter, crown length and leaf area can differ between mixtures and monocultures (Pretzsch 2014). For instance, individuals of European beech growing in mixture with Norway spruce showed greater crown volumes when compared to those in pure stands (Bayer et al. 2013). Beech crown plasticity was also detected when growing in pine admixture, with larger crown sizes than in pure stands (Dieler and Pretzsch 2013). These differences in crown architecture, as well as interspecific differences in height, can result in a more efficient packing of tree crowns within the canopy space as illustrated in Fig. 9 and an increased light absorption by individual tree crowns of a given species and size in mixtures compared with monocultures (Forrester and Albrecht 2014; Sapijanskas et al. 2014). Furthermore, canopy filling-diversity relationships when growing in mixtures have found to be constant despite differences in species composition and climate among sites (Jucker et al. 2015). However, canopy space filling seems more affected by architectural properties of the species in the mixture rather than by species richness itself (Seidel et al. 2013; Barbeito et al. 2014).

The higher plasticity in canopy shape and volume in mixtures in response to changes in the local neighbourhood increases canopy occupation, maximizing light interception and thereby increasing productivity. The other side of the high plasticity and increased light interception of beech in mixed stands compared with pure stands might be a 
(a)

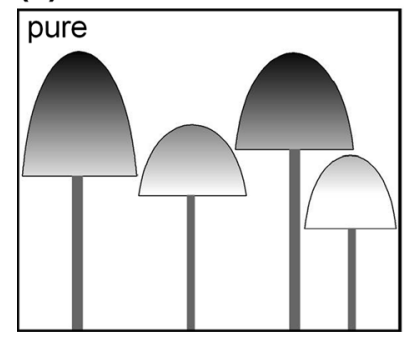

(b)

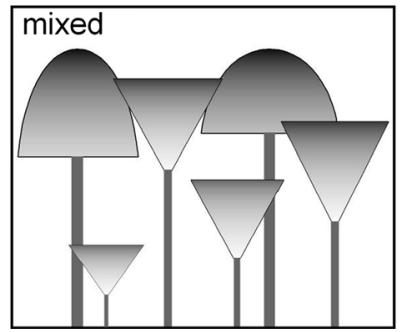

(c)

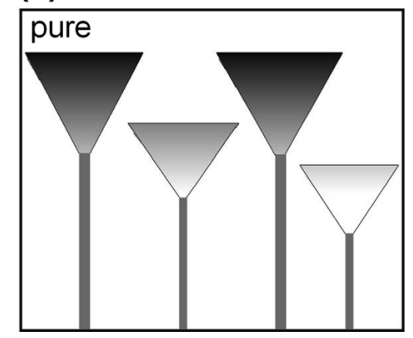

Fig. 9 Forest canopy can be denser in mixed stands $\mathbf{b}$ compare with pure stands, a, c due to wider tree crown extension, multi-layering, and higher stocking density. The more complete canopy space filling may increase the light interception in mixed stands. Replacement of inefficient organs or trees of one species by more efficient neighbours of the other species may increase the light-use efficiency. Black hatching means high efficiency of light use, grey and white indicates medium and low efficiency decrease in wood quality due to higher crown asymmetry and stem curvature in mixtures (Knoke and Seifert 2008).

\section{Spatial dynamics of overyielding in pine and beech mixtures}

The stress-gradient hypothesis (SGH) states that facilitation dominates species interactions under high stress levels (as, e.g., by resource limitation), whereas competition dominates in the absence of limitation (Callaway and Walker 1997; Holmgren et al. 1997). The SGH refers to facilitative interactions, but other complementary interactions that reduce competition (e.g. spatial, temporal or chemical stratification in water and nutrient sources and uptake) can also lead to overyielding. If underlying mechanisms are not directly studied, it is difficult to separate the effects of facilitation and competitive reduction and to apply the SGH in forests. However, if facilitation and competitive reduction are considered in combination, quantified here as overyielding (and elsewhere as complementarity), general spatial patterns have also been found in forests (Forrester 2014). That is, as the availability of a given resource declines along a spatial gradient, overyielding (or complementarity effects) for a given species will increase if the interactions between species increase the availability or use efficiency of that resource (Forrester 2014). On average over all triplets, the overyielding in terms of volume productivity was $8 \%$ for the whole stand, $10 \%$ for Scots pine, and $9 \%$ for European beech, so clearly there are complementary interactions occurring in these stands.

The absence of a significant relationship between overyielding and site index or climate variables for either species may result from a balance between the effects of different types of interactions (light-, water- and nutrientrelated) that are all occurring in these stands but are each important at different ages, sites, and under different climatic conditions. We speculate that interactions that improve light absorption and use may be important at the more productive sites, while a long-term positive feedback between stand and site conditions might improve the humus conditions, water storage and nutrient supply due to an enhanced turnover, resource supply and resource-use efficiency (Binkley et al. 2004; Jonard et al. 2008; Sariyildiz and Anderson, 2003). More detailed analyses will be required to test these hypotheses.

\section{Conclusions and perspectives}

The prevailing complementarity, overyielding, and overdensity of mixed compared with pure stands on most of the 32 sites is of practical relevance because mixed stands of Scots pine and European beech are on the advance in Europe.

In response to overuse and exploitation of forests and a rising demand for timber about 200 years ago, large forest areas, which naturally were dominated by broadleaved species, have been reforested with pure pine plantations. Because of its wide ecological amplitude and fast growth, Scots pine appeared to be the right species for this purpose. When the soils were not too dry and poor in mineral nutrients, European beech often naturally regenerated between the planted or sown pine and had to be cleared several times, because of sprouting, before the pine stands could finally become established (Milnik 2007). Additionally, in many Central European forest areas, litter raking and clear cutting left heavily degraded soils (Kral et al. 1970). In spite of re-afforesting these large clear cuts with Norway spruce, Scots pine regenerated naturally and soon overgrew the planted spruce, thus leaving stands with pine in the overstory and poorly growing beech or spruce in the understory. It only slowly became evident that these pure conifer stands were more susceptible to damage by storms, snow, ice, droughts, insects and fungi, and were 
accompanied by a loss of biodiversity (see e.g. Spiecker 2003; Baumgarten and von Teuffel 2005). Therefore, since the 1970s, the conversion of these monocultures to mixed stands was initiated, frequently with beech or oak. Additional impetus for conversion was gained from an attitude of close-to-nature-forestry and a need to adaptive forest management in the face of global changes. The acid rain period revealed that pure conifer stands will lead to an additional acidification of the soils, which could be effectively counteracted by adding beech to the conifers (Berger et al. 2006). Furthermore, the natural area where pine and beech coexist in the southwestern limit of the distributions of the two species has risen during last few decades (Hernández et al. 2013), increasing the importance of this mixture in forest practice.

Silvicultural guidelines and objectives for mixed stands of Scots pine and European beech should consider the site's moisture and fertility, as well as climatic conditions. On dry sandy soils with poor nutrition, both species can be regenerated at the same time by means of single or group admixture systems. However, European beech in this case is usually dominated by Scots pine and therefore, due to its large tolerance for shade, remains as an understorey (Tyszkiewicz and Obmiński 1963; Kint et al. 2006). This can be observed at the eastern edge of the European beech range in more central and eastern Poland, where the harsh continental climate prevails (Rubner and Reinhold 1953; Bolte et al. 2007). In such cases, Sokołowski (1912, p. 352) recommends giving a temporal advantage to European beech by planting it in advance under the canopy of mature Scots pines. Afterwards, Scots pine should be introduced to the new stand, either by means of natural or artificial regeneration. On moist and fertile sites, and sites under a higher influence of the Atlantic climate, European beech will already outcompete Scots pine during the early stand development phases. Thus, in this case spatial or temporal separation of both tree species is needed in order to keep both tree species within the stand. This can be achieved either by employing group and cluster admixture systems or planting European beech under the canopy of Scots pine at the beginning of the pole stage (Tyszkiewicz and Obmiński 1963, p. 672). On the mesotrophic sites, where the competitive strength of both species is more balanced, it is possible to use the ecological benefits from smaller admixture systems such as tree-to-tree, group or row wise arrangements. In this case it is possible to intensively mix European beech and Scots pine and shape more even-age stands (Schwappach 1930).

Several studies reported that inter-annual growth variability and its dependence on climatic conditions are modulated by species composition (Lebourgeois et al. 2013; Pretzsch et al. 2013b; Río et al. 2014b), therefore indicating the important role of species composition when evaluating forest vulnerability to climate change and when defining adaptive measures. However, the potential benefit of mixing reducing the sensitivity to drought events in comparison with pure stands depends on species composition and sites. Studies have reported positive (Lebourgeois et al. 2013; Pretzsch et al. 2013b), neutral (Jucker et al. 2014; Merlin et al. 2015), or even negative effects (Grossiord et al. 2014). It is therefore crucial to further explore the spatial and temporal variation of overyielding in Scots pine-European beech forest in order to determine the potential of this mixture in the face of climate change.

Acknowledgments The networking in this study has been supported by COST Action FP1206 EuMIXFOR. All contributors thank their national funding institutions to establish, measure, and analyse data from the triplets. The first author also thanks the Bayerischen Staatsforsten (BaySF) for supporting the establishment of the plots, the Bavarian State Ministry for Nutrition, Agriculture, and Forestry for permanent support of the project W 07 "Long-term experimental plots for forest growth and yield research" (\# 7831-22209-2013) and the German Science Foundation for providing the funds for the projects PR 292/12-1 "Tree and stand-level growth reactions on drought in mixed versus pure forests of Norway spruce and European beech". Thanks are also due to Ulrich Kern for the graphical artwork, and to two anonymous reviewers for their constructive criticism.

Open Access This article is distributed under the terms of the Creative Commons Attribution 4.0 International License (http://crea tivecommons.org/licenses/by/4.0/), which permits unrestricted use, distribution, and reproduction in any medium, provided you give appropriate credit to the original author(s) and the source, provide a link to the Creative Commons license, and indicate if changes were made.

\section{References}

Ammer S, Weber K, Abs C, Ammer C, Prietzel J (2006) Factors influencing the distribution and abundance of earthworm communities in pure and converted Scots pine stands. Appl Soil Ecol 33:10-21

Assmann E (1970) The principles of forest yield study. Pergamon Press Ltd., Oxford

Augusto L, Ranger J, Binkley D, Rothe A (2002) Impact of several common tree species of European temperate forests on soil fertility. Ann For Sci 59:233-253

Augusto L, De Schrijver A, Vesterdal L, Smolander A, Prescott C, Ranger J (2015) Influences of evergreen gymnosperm and deciduous angiosperm tree species on the functioning of temperate and boreal forests. Biol Rev 90:444-466

Barbeito I, Collet C, Ningre F (2014) Crown responses to neighbor density and species identity in a young mixed deciduous stand. Trees 28:1751-1765

Baumgarten M, von Teuffel K (2005) Nachhaltige Waldwirtschaft in Deutschland. In: von Teuffel K, Baumgarten M, Hanewinkel M, Konold W, Sauter UH, Spiecker H, von Wilpert K (Hrsg.): Waldumbau: 1-10. Springer, Berlin

Bayer D, Seifert S, Pretzsch H (2013) Structural crown properties of Norway spruce (Picea abies L. Karst.) and European beech (Fagus sylvatica L.) in mixed versus pure stands revealed by terrestrial laser scanning. Trees 27:1035-1047

Begon ME, Harper JL, Townsend CR (1998) Ökologie. Spektrum Akademischer Verlag, Heidelberg 
Berger TW, Swoboda S, Prohaska T, Glatzel G (2006) The role of calcium uptake from deep soils for spruce (Picea abies) and beech (Fagus sylvatica). For Ecol Manag 229:234-246

Bielak K, Dudzińska M, Pretzsch H (2014) Mixed stands of Scots pine (Pinus sylvestris L.) and Norway spruce [Picea abies (L.) Karst] can be more productive than monocultures. Evidence from over 100 years of observation of long-term experiments. For Syst 23(3):573-589

Bielak K, Dudzińska M, Pretzsch H (2015) Przyrost miąższości drzewostanów mieszanych i litych: wyniki z wybranych stałych powierzchni badawczych w Europie Srodkowej. Sylwan 159(1): 22-35

Binkley D, Dunkin KA, DeBell D, Ryan MG (1992) Production and nutrient cycling in mixed plantations of eucalyptus and albizia in Hawaii. For Sci 38:393-408

Binkley D, Stape JL, Ryan MG (2004) Thinking about efficiency of resource use in forests. For Ecol Manag 193:5-16

Bohn U, Gollup G, Hettwer C, Neuhäuslova Z, Schlüter H (2003) Map of the natural vegetation of Europe, scale 1:2.5 million. Federal Agency for Nature Conservation, Bonn-Bad Godesberg

Bolte A, Czajkowski T, Kompa T (2007) The north-eastern distribution range of European beech-a review. Forestry 80(4):413-429

Bonnemann A (1939) Der gleichaltrige Mischbestand von Kiefer und Buche. Mitt Forstwirtsch u Forstwiss, $45 \mathrm{p}$

Brus DJ, Hengeveld GM, Walvoort DJJ, Goedhart PW, Heidema AH, Nabuurs GJ, Gunia K (2011) Statistical mapping of tree species over Europe. Eur J For Res 131(1):145-157

Brzeziecki B, Kienast F (1994) Classifying the life-history strategies of trees on the basis of the Grimian model. For Ecol Manag 69(1-3): 1675-1687

Caldwell MM, Dawson TE, Richards JH (1998) Hydraulic lift: consequences of water efflux from the roots to plants. Oecologia 113:151-161

Callaway RM, Walker LR (1997) Competition and facilitation: a synthetic approach to interactions in plant communities. Ecology 78(7): 1958-1965

Chodzicki E (1934) Buchen-Beimischung in Kiefernbeständen. Als edaphischer Faktor auf diluvialen, sandigen Podsol und Braunerden. Diss. Sklad Glówny Kasa im. Mianowskiego 72:229-254

Condés S, del Río M, Sterba H (2013) Mixing effect on volume growth of Fagus sylvatica and Pinus sylvestris is modulated by stand density. For Ecol Manag 292:86-95

Czajkowski T, Bolte A (2006) Frosttoleranz deutscher und polnischer Herkünfte der Buche (Fagus sylvatica L.) und ihre Beeinflussung durch Trockenheit. Arch Forstwes Landschökol 40:119-126

de Martonne E (1926) Une novelle fonction climatologique: L'indice d'aridité. La Météorologie 21:449-458

Dieler J, Pretzsch H (2013) Morphological plasticity of European beech (Fagus sylvatica L.) in pure and mixed-species stands. For Ecol Manag 295:97-108

Dirnberger GF, Sterba H (2014) A comparison of different methods to estimate species proportions by area in mixed stands. For Syst 23(3):534-546

Dittmar C, Fricke W, Elling W (2006) Impact of late frost events on radial growth of common beech (Fagus sylvatica L.) in Southern Germany. Eur J For Res 125:249-259

Ehwald E, Grunert F, Schultz W, Vetterlein E (1961) Zur Ökologie von Kiefern-Buchen Mischbeständen. Archiv für Forstwesen 10:397-415

Ellenberg H, Leuschner C (2010) Vegetation Mitteleuropas mit den Alpen in ökologischer, dynamischer und historischer Sicht. Eugen Ulmer, Stuttgart

Fischer A, Fischer H (2012) Restoration of temperate forests: an European approach. In: van Andel J, Aronson J (eds) Restoration ecology: the new frontier, 2nd edn. Blackwell Publishing Ltd., Chap 12, pp 145-160
Fisichelli N, Vor T, Ammer C (2014) Broadleaf seedling responses to warmer temperatures "chilled" by late frost that favors conifers. Eur J For Res 133:587-596

Forrester DI (2014) The spatial and temporal dynamics of species interactions in mixed-species forests: from pattern to process. For Ecol Manag 312:282-292

Forrester DI (2015) Transpiration and water-use efficiency in mixedspecies forests versus monocultures: effects of tree size, stand density and season. Tree Physiol 35:289-304

Forrester DI, Albrecht AT (2014) Light absorption and light-use efficiency in mixtures of Abies alba and Picea abies along a productivity gradient. For Ecol Manag 328:94-102

Forrester DI, Bauhus J, Cowie AL, Vanclay JK (2006) Mixed-species plantations of Eucalyptus with nitrogen-fixing trees: a review. For Ecol Manag 233:211-230

Forrester DI, Lancaster K, Collopy JJ, Warren CR, Tausz M (2012) Photosynthetic capacity of Eucalyptus globulus is higher when grown in mixture with Acacia mearnsii. Trees 26:1203-1213

Franz F (1971) Funktionen und Tabellen der Derbholzformhöhen für die wichtigsten Baumarten in Bayern. München, Manuskriptdruck, unveröffentlicht

Franz F, Bachler J, Deckelmann E, Kennel E, Kennel R, Schmidt A, Wotschikowsky U (1973) Bayerische Waldinventur 1970/71. Inventurabschnitt I: Großrauminventur Aufnahme- und Auswertungsverfahren. Forstliche Versuchsanstalt München, vol 11, $143 \mathrm{p}$

Gabriel K, Blair FI, Mason WL (2005) Growing broadleaved trees on the North York Moors-results after nearly 50 years. Q J For 99:21-30

Geßler A, Keitel C, Nahm M, Rennenberg H (2004) Water shortage affects the water and nitrogen balance in central European beech forests. Plant Biol 6:289-298

Geßler A, Keitel C, Kreuzwieser J, Matyssek R, Seiler W, Rennenberg H (2007) Potential risks for European beech (Fagus sylvatica $\mathrm{L}$.) in a changing climate. Trees 21:1-11

Griess VC, Knoke Th (2011) Growth performance, windthrow, and insects: meta-analyses of parameters influencing performance of mixed-species stands in boreal and northern temperate biomes. Can J For Res 41:1141-1158

Grossiord C, Granier A, Ratcliffe S, Bouriaud O, Bruelheide H, Chećko E, Forrester DI, Dawud SM, Finér L, Pollastrini M, Scherer-Lorenzen M, Valladares F, Bonal D, Gessler A (2014) Tree diversity does not always improve resistance of forest ecosystems to drought. PNAS 111:14812-14815

Häberle K-H, Weigt R, Nikolova P, Reiter IM, Cermak J, Wieser G, Blaschke H, Rötzer T, Pretzsch H, Matyssek R (2012) Case study „Kranzberger Forst“-growth and defence in European beech (Fagus sylvatica) and Norway spruce (Picea abies). In: Matyssek R, Schnyder, H, Oßwald W, Ernst D, Munch C, Pretzsch H (eds) Growth and defence in plants. Springer, Berlin. Ecol Stud. doi:10.1007/978-3-642-30645-7

Hartmann H (2011) Will a 385 million year-struggle for light become a struggle for water and for carbon?-How trees may cope with more frequent climate change-type drought events. Glob Change Biol 17(1):642-655

Heinsdorf D (1999) Das Revier Sauen - Ein Beispiel für erfolgreichen Waldumbau, Schriftenreihe des Ministeriums für Ernährung, Landwirtschaft und Forsten, Eberswalder Forstliche Schriftenreihe, Landesforstanstalt Eberswalde, Ministerium für Ernährung, Landwirtschaft und Forsten, Brandenburg, Band VI, $30 \mathrm{p}$

Hernández L, Cañellas I, Alberdi I, Torres I, Montes F (2013) Assessing changes in species distribution from sequential largescale fores inventories. Ann For Sci 71:161-171

Holmgren M, Scheffer M, Huston MA (1997) The interplay of facilitation and competition in plant communities. Ecology 78(7):1966-1975 
Holmsgaard E (1962) The influence of weather on growth and reproduction of beech. Comm Inst For Fenniae 55:1-5

Huber MO, Sterba H, Bernhard L (2014) Site conditions and definition of compositional proportion modify mixture effects in Picea abies-Abies alba stands. Can J For Res 44(10):1281-1291

Johann K (1993) DESER-Norm 1993. Normen der Sektion Ertragskunde im Deutschen Verband Forstlicher Forschungsanstalten zur Aufbereitung von waldwachstumskundlichen Dauerversuchen. Proc Dt Verb Forstl Forschungsanst, Sek Ertragskd, in Unterreichenbach-Kapfenhardt, pp 96-104

Jonard M, André F, Ponette Q (2008) Tree species mediated effects on leaf litter dynamics in pure and mixed stands of oak and beech. Can J For Res 38:528-538

Jönsson AM (2000) Soil treatment effects on bark lesions and frost sensitivity of beech (Fagus sylvatica) in southern Sweden. For Ecol Manag 129:167-175

Jucker T, Bouriaud O, Avacaritei D, Dănilă I, Duduman G, Valladares F, Coomes DA (2014) Competition for light and water play contrasting roles in driving diversity-productivity relationships in Iberian forests. J Ecol 102(5):1202-1213

Jucker T, Bouraiud O, Coomes DA (2015) Crown plasticity enables trees to optimize canopy packing in mixed-species forests. Funct Ecol. doi:10.1111/1365-2435.12428

Kelty MJ (1992) Comparative productivity of monocultures and mixed stands. In: Kelty MJ, Larson BC, Oliver CD (eds) The ecology and silviculture of mixed-species forests. Kluwer Academic Publishers, Dordrecht, pp 125-141

Kennel R (1972) Die Buchendurchforstungsversuche in Bayern von 1870 bis 1970. Forstliche Versuchsanstalt München vol 7

Kint V, Geudens G, Mohren GMJ, Lust N (2006) Silvicultural interpretation of natural vegetation dynamics in ageing Scots pine stands for their conversion into mixed broadleaved stands. For Ecol Manag 223:363-370

Knapp E (1991) Zur Wuchsleistung der Unterbaubuche im ungleichaltrigen Kiefern-Buchen-Mischbestand vor und nach ihrer Übernahme als Hauptbestand auf Standorten des norostdeutschen Tieflandes, Bericht von der Jahrestagung 1991 der Sektion Ertragskunde im Deutschen Verband Forstlicher Forschungsanstalten in Treis-Karden/Mosel, pp 96-110

Knoke Th, Seifert Th (2008) Integrating selected ecological effects of mixed European beech-Norway spruce stands in bioeconomic modelling. Ecol Model 210:487-498

Knoke T, Ammer H, Stimm B, Mosandl R (2008) Admixing broadleaved to coniferous tree species: a review on yield, ecological stability and economics. Eur J For Res 127:89-101

Kolström M, Lindner M, Vilén T, Maroschek M, Seidl R, Lexer MJ, Netherer S, Kremer A, Delzon S, Barbati A, Marchetti M, Corona P (2011) Reviewing the science and implementation of climate change adaptation measures in European forestry. Forests 2:961-982

Kral F, Mayer H, Nather J, Pollanschütz J, Rachoy W (1970) Naturverjüngung im Mischwald, Bestandesumbau sekundärer Kiefernwälder. Mitt. Forstl. Bundes-versuchsanstalt Wien, 90

Lebourgeois F, Gomez N, Pinto P, Mérian P (2013) Mixed stands reduce Abies alba tree-ring sensitivity to summer drought in the Vosges mountains, western European. J For Res 303:61-71

Leuschner C, Meier IC, Hertel D (2006) On the niche breadth of Fagus sylvatica: soil nutrient status in 50 Central European beech stands on a broad range of bedrock types. Ann For Sci 63:335-368

Mantel W (1961) Wald und Forst. Wechselbeziehungen zwischen Natur und Wirtschaft, Rowohlts deutsche Enzyklopädie, Rowohlt, Hamburg

McDowell N, Pockman WT, Allen CD, Breshears DD, Cobb N, Kolb T, Plaut J, Sperry J, West A, Williams DG, Yepez EA (2008) Mechanisms of plant survival and mortality during drought: why do some plants survive while others succumb to drought? New Phytol 178(4):719-739

McElhinny C, Gibbons P, Brack C, Bauhus J (2005) Forest and woodland stand structural complexity: its definition and measurement. For Ecol Manag 218:1-24

Merlin M, Perot T, Perret S, Korboulewsky N, Vallet P (2015) Effects of stand composition and tree size on resistance and resilience to drought in sessile oak and Scots pine. For Ecol Manag 339:22-33

Metz J, Seidel D, Schall P, Scheffer D, Schulze E-D, Ammer C (2013) Crown modeling by terrestrial laser scanning as an approach to assess the effect of aboveground intra- and interspecific competition on tree growth. For Ecol Manag 310:275-288

Milnik A (2007) Zur Geschichte der Kiefernwirtschaft in Nordostdeutschland. In: Kätzel R, Möller K, Löffler S, Engel J, Liero K (eds) Die Kiefer im nordostdeutschen Tiefland - Ökologie und Bewirtschaftung. Eberswalder Schriftenreihe XXXII:14-21

Monserud RA, Sterba H (1999) Modeling individual tree mortality for Austrian forest species. For Ecol Manag 113:109-123

Morin X, Fahse L, Scherer-Lorenzen M, Bugmann H (2011) Tree species richness promotes productivity in temperate forests through strong complementarity between species. Ecol Lett 14: 1211-1219

Paquette A, Messier C (2011) The effect of biodiversity on tree productivity: from temperate to boreal forests. Glob Ecol Biogeogr 20(1):170-180

Perot T, Picard N (2012) Mixture enhances productivity in a twospecies forest: evidence from a modeling approach. Ecol Res 27(1):83-94

Petterson H (1955) Die Massenproduktion des Nadelwaldes. Mitteilung der Forstlichen Versuchsanstalt Schwedens 45(1):1-391

Piotto D (2008) A meta-analysis comparing tree growth in monocultures and mixed plantations. For Ecol Manag 255(3):781-786

Pirogowicz T (1990) Produkcyjność drzewostanów sosnowych podsadzonych bukiem w Strzałowie i Polnicy. Produktivität von Kieferbeständen waterpflantz mit Buchen in Strzałowo und Polnica. Prace IBL 721:86-101 [in Polish with German summary]

Pretzsch H (2006) Species-specific allometric scaling under selfthinning. Evidence from long-tern plots in forest stands. Oecologia 146:572-583

Pretzsch H (2009) Forest dynamics, growth and yield. From measurement to model. Springer, Berlin

Pretzsch H (2014) Canopy space filling and tree crown morphology in mixed-species stands compared with monocultures. For Ecol Manag 327:251-264

Pretzsch H, Biber P (2005) A re-evaluation of Reineke's rule and stand density index. For Sci 51:304-320

Pretzsch H, Schütze G (2009) Transgressive overyielding in mixed compared with pure stands of Norway spruce and European beech in Central Europe: evidence on stand level and explanation on individual tree level. Eur J For Res 128:183-204

Pretzsch H, Block J, Dieler J, Dong PH, Kohnle U, Nagel J, Spellmann H, Zingg A (2010) Comparison between the productivity of pure and mixed stands of Norway spruce and European beech along an ecological gradient. Ann For Sci 67:1-12

Pretzsch H, Bielak K, Block J, Bruchwald A, Dieler J, Ehrhart H-P, Kohnle U, Nagel J, Spellmann H, Zasada M, Zingg A (2013a) Productivity of pure versus mixed stands of oak (Quercus petraea (MATT.) LIEBL. and Quercus robur L.) and European beech (Fagus sylvatica L.) along an ecological gradient. Eur J For Res 132(2):263-280

Pretzsch H, Schütze G, Uhl E (2013b) Resistance of European tree species to drought stress in mixed versus pure forests: evidence of stress release by inter-specific facilitation. Plant Biol 15: 483-495

Pretzsch H, Bielak K, Bruchwald A, Dieler J, Dudzinska M, Ehrhart HP, Jensen AM, Johannsen VK, Kohnle U, Nagel J, Spellmann 
H, Zasada M, Zingg A (2013c) Mischung und Produktivität von Waldbeständen. Ergebnisse langfristiger ertragskundlicher Versuche. Allgemeine Forst-und Jagdzeitung 184(7/8):177-196

Pretzsch H, Rötzer T, Matyssek R, Grams TEE, Häberle KH, Pritsch K, Kerner R, Munch JC (2014) Mixed Norway spruce (Picea abies [L.] Karst) and European beech (Fagus sylvatica [L.]) stands under drought: from reaction pattern to mechanism. Trees 28:1305-1321

Pretzsch H, Forrester DI, Rötzer Th (2015) Representation of species mixing in forest growth models. A review and perspective. Ecol Model. doi:10.1016/j.ecolmodel.2015.06.044

Prévosto B, Balandier P (2007) Influence of nurse birch and Scots pine seedlings on early aerial development of European beech seedlings in an open-field plantation of Central France. Forestry 80(3):253-264

Quan C, Han S, Utescher T, Zhang C, Liu YS (2013) Validation of temperature-precipitation based aridity index: paleoclimatic implications. Palaeogeogr Palaeoclimatol Palaeoecol 386:86-95

Reineke LH (1933) Perfecting a stand-density index for even-aged forests. J Agric Res 46:627-638

Richards AE, Forrester DI, Bauhus J, Scherer-Lorenzen M (2010) The influence of mixed tree plantations on the nutrition of individual species: a review. Tree Physiol 30(9):1192-1208

Río M, Sterba H (2009) Comparing volume growth in pure and mixed stands of Pinus sylvestris and Quercus pyrenaica. Ann For Sci 66(5):1-11

Río M, Condés S, Pretzsch H (2014a) Analyzing size-symmetric vs. size-asymmetric and intra-vs. inter-specific competition in beech (Fagus sylvatica L.) mixed stands. For Ecol Manag 325:90-98

Río M, Schütze G, Pretzsch H (2014b) Temporal variation of competition and facilitation in mixed species forests in Central Europe. Plant Biol 16:166-176

Rothe A, Binkley D (2001) Nutritional interactions in mixed species forests: a synthesis. Can J For Res 31:1855-1870

Rubner K, Reinhold F (1953) Das natürliche Waldbild Europas als Grundlage für einen europäischen Waldbau. Parey, HamburgBerlin

Ruiz-Benito P, Lines ER, Gómez-Aparicio L, Zavala MA, Coomes DA (2013) Patterns and drivers of tree mortality in Iberian forests: climatic effects are modified by competition. PLoS ONE 8:e56843

Sapijanskas J, Paquette A, Potvin C, Kunert N, Loreau M (2014) Tropical tree diversity enhances light capture through crown plasticity and spatial and temporal niche differences. Ecology 95:2479-2492

Sariyildiz T, Anderson JM (2003) Interactions between litter quality, decomposition and soil fertility: a laboratory study. Soil Biol Biochem 35(3):391-399
Schober R (1967) Buchen-Ertragstafel für mäßige und starke Durchforstung, In: Schober R (1972) Die Rotbuche 1971. Schr Forstl Fak Univ Göttingen u Niedersächs Forstl Versuchsanst 43/44, JD Sauerländer's Verlag, Frankfurt am Main, 333 p

Schütz J-Ph (2001) Der Plenterwald und weitere Formen strukturierter und gemischter Wälder. Parey, Berlin

Schwappach A (1930) Die Verjüngung von Kiefern-Buchen Mischbeständen im norddeutschen Sandergebiet. Zeitschrift für Forst-und Jagdwesen VII, VIII

Seidel D, Leuschner C, Scherber C, Beyer F, Wommelsdorf T, Cashman MJ, Fehrmann L (2013) The relationship between tree species richness, canopy space exploration and productivity in a temperate broad-leaf mixed forest. For Ecol Manag 310:366-374

Sokołowski S. (1912) Hodowla Lasu (Silviculture). Lwów, 374 p

Spiecker H (2003) Silvicultural management in maintaining biodiversity and resistance of forests in Europe-temperate zone. J Environ Manag 67:55-65

Spies TA, Franklin JF (1991) The structure of natural, young, mature, and old-growth Douglas-fir forests in Oregon and Washington. In: USDA Forest Service General technical Report PNW-GTR. Pacific Northwest Research Station, Portland (OR), pp 91-109

Tyszkiewicz S, Obmiński Z (1963) Hodowla i uprawa lasu. PWRiL, Warszawa

Vallet P, Perot T (2011) Silver fir stand productivity is enhanced when mixed with Norway spruce: evidence based on large-scale inventory data and a generic modelling approach. J Veg Sci 22(5):932-942

von Mammen A, Bachmann M, Prietzel J, Pretzsch H, Rehfuess KE (2003) Bodenzustand, Ernährungszustand und Wachstum von Fichten (Picea abies Karst.) auf Probeflächen des Friedenfelser Verfahrens in der Oberpfalz, Forstwissenschaftliches Centralblatt, 122. Jg., S. 99-114

Wiedemann E (1943) Die Kiefer. In Schober 1974: Ertragstafeln wichtiger Baumarten. J.D. Sauerländer's Verlag, Frankfurt a. M., $337 \mathrm{p}$

Zellweger F, Braunisch V, Baltensweiler A, Bollmann K (2013) Remotely sensed forest structural complexity predicts multi species occurrence at the landscape scale. For Ecol Manag 307:303-312

Zhang Y, Chen HYH, Reich PB (2012) Forest productivity increases with evenness, species richness and trait variation: a global metaanalysis. J Ecol 100(3):742-749

Zhao D, Borders B, Wilson M, Rathbun SL (2006) Modeling neighborhood effects on the growth and survival of individual trees in a natural temperate species-rich forest. Ecol Model 196(1):90-102 